\title{
Viðhorf íslenskra og danskra stjórnenda til starfsumhverfis í ljósi norrænna gilda
}

\author{
Bergbóra Hlín Arnórsdóttir, sérfræđingur hjá Fræđslumiðstöð atvinnulífsins \\ Einar Svansson, lektor viđ Háskólann á Bifröst \\ Kári Joensen, lektor við Háskólann á Bifröst.
}

\begin{abstract}
Útdráttur
Norræn forysta byggir á gildum sem notið hafa aukinnar athygli og vinsælda. Viðfangsefni greinarinnar er að fjalla um opinbera stjórnun á Íslandi og skoða hvort og pá með hvaða hætti íslenskir stjórnendur falla að gildum norrænnar forystu. Gerð var rannsókn að danskri fyrirmynd sem nefnist Opinberir stjórnendur - verkefni og viðhorf. Spurningalisti í formi vefkönnunar var lagður fyrir 1.685 opinbera stjórnendur, 524 svör bárust eða 31\%. Megintilgangur rannsóknarinnar var að draga fram áherslur íslenskra stjórnenda í daglegum störfum, viðhorfum til starfsumhverfis og pess ramma sem unnið er ́́. Skoðað var starfsumhverfi íslenskra og danskra stjórnenda í samhengi við norræn gildi. Helstu niðurstöður benda til pess að opinber stjórnun á Íslandi einkennist af trausti, skýrum verkferlum, stuttum boðleiðum og litlu skrifræði. Helstu hindranir voru lítil áhrif á löggjöf og pólitískt bakland, tækifæri felast hins vegar í að hafa meiri áhrif og auka árangur í starfseminni. Samstarf og tengslanet var gott á vinnustaðnum og sanngjarnar kröfur voru gerðar til stjórnenda. Sérstaða hvors hóps fólst í pví að danskir stjórnendur töldu skrifræði vera of mikið og að einfalda mætti verkferla í pví sambandi. Íslenskir stjórnendur virtust hins vegar almennt hafa minni áhrif á starfsumhverfið en danskir starfsfélagar. Verkefni og viðhorf íslenskra opinberra stjórnenda ríma við norræn gildi par sem opin samskipti, gagnrýni í hugsun og umhyggja eru helstu einkennin.
\end{abstract}

Efnisord: Norræn forysta; opinber stjórnun; íslenskir stjórnendur; starfsumhverfi.

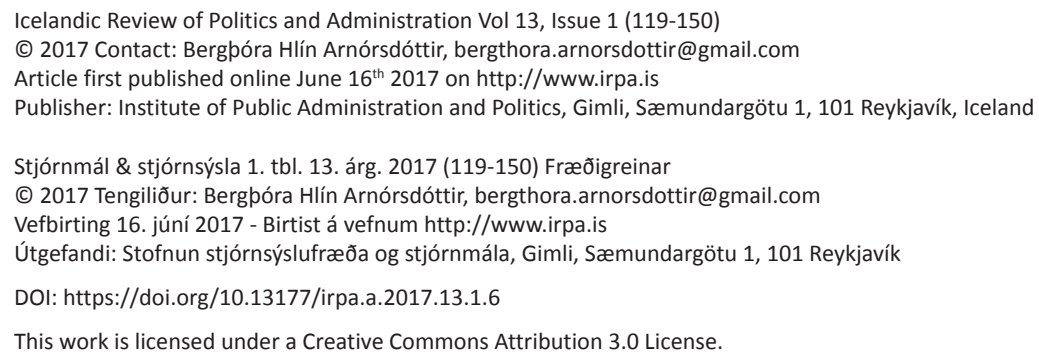




\section{Comparison of Icelandic and Danish managers' evaluation of their working environment in light of Nordic values}

\section{Abstract}

Nordic leadership values have gained increased publicity and popularity recently. The paper looks at Icelandic public management. The main research question is if and how Icelandic managers adhere to Nordic leadership values. The research is based on a prior Danish study: Public managers - tasks and opinions. An online questionnaire was sent to 1.685 public managers in Iceland, with 524 respondents so the participation rate is $31 \%$. The main purpose of the research was to highlight the emphasis of Icelandic managers in daily tasks and get their opinions on their working environment and regulatory framework. Another point was to compare the public working environment in Iceland and Denmark regarding the basic values of Nordic leadership.

The main findings show that public management in Iceland is characterized by trust, clear work-processes, short chains of command and minimal bureaucracy. Cooperation and social networking at the workplace was positive and reasonable demands towards the managers. At the same time, there seem to be opportunities for the managers to have more influence to enhance performance in their institutions. The main barriers were minimal influence on legislation and the political stakeholders. In comparison, the Danish managers thought bureaucracy too burdensome and that work-processes could be simplified. However, the Danish managers feel they have greater impact and influence on their working environment and political stakeholders.

The work-processes and perspectives of Icelandic managers are in line with the Nordic management values: Open communication, critical thinking and care.

Keywords: Nordic leadership; public management; Icelandic managers; working environment.

\section{Inngangur}

Í pessari grein er leitast við að draga upp mynd af norrænni forystu, fjallað um opinbera stjórnun á Íslandi og skoðaðir stjórnunarferlar og einkenni peirra með tilliti til norrænnar forystu. Áhugavert er að skoða hvernig íslenskir og danskir stjórnendur falla að norrænum gildum með tilliti til viðhorfa og starfa í ljósi pess að oft er pví haldið fram að frændpjóðirnar á Norðurlöndum deili sömu áherslum í stjórnun par sem lífsgæði eru með peim bestu sem pekkjast í heiminum. Norræn forysta einkennist af áherslu á samfélagsleg gildi, fjölbreytni og velferð borgaranna. Dessi stjórnunarstíll nýtur mikilla vinsælda í heiminum um pessar mundir vegna pess að hann skapar árangur sem pykir eftirsóknarverður.

Mikilvægt er fyrir stjórnendur að ná sem bestum árangri í starfi með tilliti til velferðar einstaklinga og samfélags. Meginspurning rannsóknarinnar sem pessi grein byggir 
á, var hvort íslenskir stjórnendur geti lært af norrænum starfsfélögum varðandi opinbera stjórnun en hér er sjónum sérstaklega beint að einni undirspurningu úr rannsókninni par sem velt er upp áherslum íslenskra stjórnenda í samanburði við danska. Í peim tilgangi var gerð könnun par sem skoðuð voru verkefni og viðhorf opinberra stjórnenda á Íslandi til starfsumhverfisins. Gerður var samanburður við danska stjórnendur og einnig skoðað hvernig viðhorf og verkefni opinberra stjórnenda í löndunum tveimur falla að gildum sem einkenna norræna stjórnun.

\section{Stjórnun og leiðtogafærni}

Stjórnun er flókið samspil aðgerða og undanfarinn áratug hefur áhersla á vinnustaðamenningu, umhverfi og aðstæður verið að aukast par sem sjálfbærni og umhverfissjónarmið hafa fengið meiri athygli ásamt jafnrétti og lýðræðislegum gildum (Yukl 2006). Stjórnun hefur próast og breyst frá upphafi síðustu aldar par sem miðstýring valds var í hávegum höfð, yfir í aukið samspil stjórnunar og leiðtogafærni. Stjórnun (e. management) snýr að reglufestu, ákvarðanatöku, eftirliti og skipulagi en leiðtogafærni (e. leadership) snýst um að hafa áhrif á starfsfólk í gegnum gildi, hefðir, eiginleika og menningu (Yukl 2006; Larsen \& Neergaard 2007; Northouse 2016). Рað er grundvallarmunur á stjórnun og forystu. Að stjórna pýðir að ná einhverju fram, að ná árangri, að bera ábyrgð á eða framkvæma. Forysta er að hafa áhrif, leiða í rétta átt. Stjórnendur gera hlutina rétt með markvissri stýringu vinnuferla sem leiðir til aukinnar skilvirkni. Leiðtogar gera réttu hlutina sem byggir á sterkri framtíðarsýn og dómgreind, sem eykur árangur í rekstri á stefnumiðaðan hátt. Leiðtogar skapa traust, stýra breytingum með pví að hvetja og hafa áhrif á starfsfólkið, yfirvinna hindranir með pví að skapa framtíðarsýn sem byggir upp sterka sjálfsmynd starfsmanna og trú á eigin getu (Bennis og Nanus 1985). Stjórnun og leiðtogafærni parf að haldast í hendur og setti Kotter (2012) fram yfirlit yfir verkefnin eins og fram kemurí töflu 1.

Tafla 1. Yfirlit yfir störf stjórnenda og leiđtoga. Framsetning höfunda, byggt á Kotter (2012)

\begin{tabular}{l|l|l}
\hline & Stjórnunarhlutverk & Leiðtogahlutverk \\
\hline Markmiðasetning & $\begin{array}{l}\text { Gera verk-, tíma- og fjárhags-áætlanir, } \\
\text { skipuleggja aðgerðir. }\end{array}$ & $\begin{array}{l}\text { Marka stefnu og framtiðđarsýn, próa leiðir } \\
\text { til breytinga. }\end{array}$ \\
\hline pjálfun & $\begin{array}{l}\text { Skipuleggja, ákveđa verkaskiptingu } \\
\text { starfsfólks, próa og tryggja verkstjórn. }\end{array}$ & $\begin{array}{l}\text { Samhæfa störf og markmið, kynna } \\
\text { framtíðarsýn og markmið, hafa áhrif á } \\
\text { myndun teyma. }\end{array}$ \\
\hline Framkvæmd & $\begin{array}{l}\text { Stýra, leysa vandamál, sinna eftirliti, } \\
\text { leiðrétta stefnu ef pörf krefur. }\end{array}$ & $\begin{array}{l}\text { Hvetja og viðhalda áhuga, vinna að } \\
\text { lausnum, uppfylla mannlegar parfir. }\end{array}$ \\
\hline Árangur & $\begin{array}{l}\text { Tryggja röð og reglu, stöđugleika og } \\
\text { fyrirsjáanleika. }\end{array}$ & $\begin{array}{l}\text { Ná fram breytingum, skapa samstöðu, } \\
\text { eftirfylgni. }\end{array}$ \\
\hline
\end{tabular}


Nútímastjórnendur purfa að hafa góða yfirsýn, skýr markmið og gera ráð fyrir óvæntum aðstæðum, par sem hver stofnun parf að viðhalda sveigjanleika og aðlögunarhæfni (Andersen \& Pors 2014). Deir purfa líka að búa yfir leiðtogafærni, sem er samsafn eiginleika sem eru nauðsynlegir til að ná virkri pátttöku og til að hafa áhrif á hóp fólks í pá átt að ná tilteknum markmiðum (Haukur Ingi Jónasson \& Helgi Pór Ingason 2011). Fjórir mikilvægir pættir hafa áhrif á stjórnunarferlið. Deir eru: valdastaða stjórnanda, persónulegir eiginleikar, verkefnið og árangur (Sørensen 2015; Fiedler 1967). Að mati Sørensen (2015) er lykilatriði við stjórnun að móta sameiginlega sýn, samhæfa aðgerðir og skapa skuldbindingu, sjá mynd 1. Ekki er sjálfgefið að einstaklingur búi yfir pessum eiginleikum við upphaf stjórnunarstarfs en petta eru mikilvægir pættir til að ná árangri í stjórnun og pað er hægt að tileinka sér pá, fá pjálfun eða leiðsögn frá öðrum reyndum stjórnendum.

\section{Mynd 1. Lykilatriði við stjórnun. Framsetning höfunda, byggt á Sørensen (2015)}

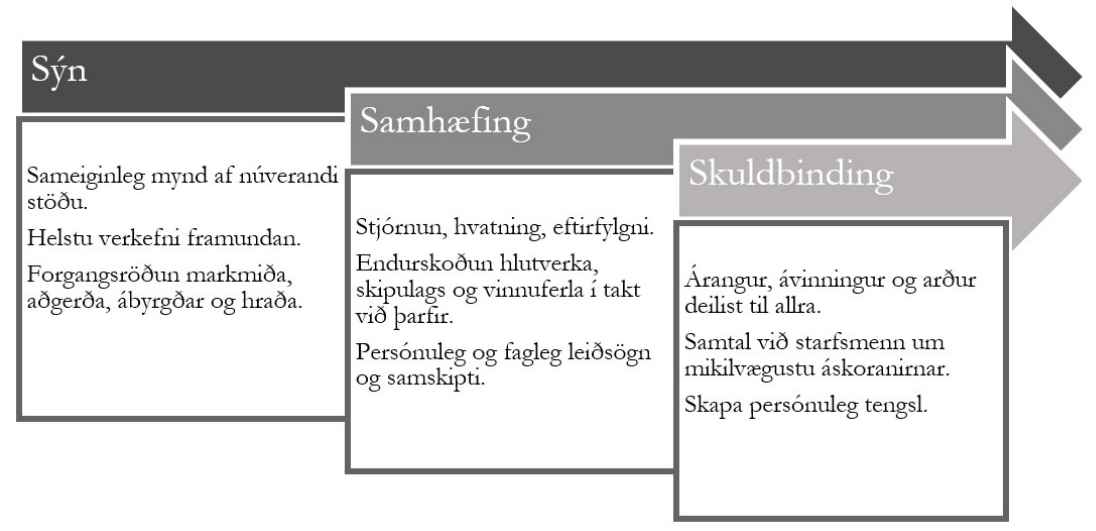

Öll lykilatriðin sem fram koma á mynd 1 eru mikils virði og stjórnun snýst um samspil peirra. Stjórnendur próa eigin færni og forgangsraða eftir pörfum fyrirtækisins með pví að styðja við aðra stjórnendur og aðstoða pá við að ná markmiðum sínum (Burnes 2014; Kotter 2012; Væksthus for ledelse 2008).

Með breyttum áherslum og auknum kröfum hefur hlutverk stjórnenda breyst, valddreifing er meiri sem lýsir sér í pví að millistjórnendur hafa fengið meiri ábyrgð. peir takast á við önnur verkefni en peir sem eru í forsvari stofnana og munur getur verið á áherslum eftir pví hverju er stjórnað (Dahl \& Søholm 2012; Burnes 2014). Millistjórnendur taka pátt í stefnumótun og áætlanagerð, sinna mikilvægu hlutverki í breytingum par sem peir eru tengiliðir við starfsfólk. Forstöðumenn nota meiri tíma í heildarskipulag og yfirsýn. Millistjórnendur hafa pekkingu á daglegum verkefnum og eru tengiliðir á milli yfirstjórnar og starfsmanna (Mintzberg 2011).

Kröfur samfélagsins um aukna pjónustu og sérfræðipekkingu hafa einnig aukist sem felur í sér að pað er mikilvægt fyrir stofnanir að hafa yfir að ráða starfsfólki sem getur hagnýtt pekkingu til að ná bættum árangri. Í nýlegri rannsókn á aðferðum pekkingarstjórnunar og pekkingarmiðlunar í sveitarfélögum á Íslandi kemur fram að í mörgum 
tilfellum er lítill greinarmunur gerður á upplýsingatækni og gæðastjórnun annars vegar og pekkingarstjórnun hins vegar og að fá sveitarfélög hafa stefnu um pekkingarstjórnun. Einnig kemur fram að mikill meirihluti svarenda telur að bæta mætti pjónustu í sveitarfélögum með markvissari miðlun pekkingar og upplýsinga (Hildur Ösp Gylfadóttir \& Ingi Rúnar Eðvarðsson 2012).

\subsection{Norræn stjórnun - gildi og vinnustađamenning}

Norræn stjórnun einkennist af gildum sem notið hafa aukinnar athygli og vinsælda í heiminum par sem velferð íbúa og samfélagsleg ábyrgð er í fyrirrúmi. Yfirleitt er talað um norræna forystu fremur en norræna stjórnun vegna pess að stjórnunarstíllinn einkennist af áherslu á að vera í forystu fyrir hópi fólks, fremur en að stýra hópnum. Ein af ástæðum pess að norrænn stjórnunarstíll pykir eftirsóknarverður er að í pessum löndum er heilbrigt og gegnsætt hagkerfi, öflugur vinnumarkaður með lítið atvinnuleysi og jafnframt ein bestu lífsgæði sem pekkjast í heiminum (Larsen \& Neergaard 2007). Fyrstu samanburðarrannsókn um norræna stjórnun gerði Poulsen (1987) sem kynnti tíu einkenni sem byggja á gildum um lýðræði, jafnræði, samvinnu og frelsi. Í rannsókn Larsen og Neergaard (2007) er varpað ljósi á hvað Norðurlöndin eiga sameiginlegt en einnig er bent á að hvert land hefur sín sérkenni sem er mikilvægt að halda til haga í norrænu samhengi. Larsen, Vestergaard og Guarini (2015) halda pví fram að norræn stjórnun einkennist af trausti, forystu með pátttöku starfsmanna, sanngirni í verkferlum og skilvirkum samskiptamynstrum sem auka fjölbreytni og gæði i stefnumótandi ákvarðanatöku.

Norrænir stjórnendur eiga margt sameiginlegt pvert á landamæri. Má nefna að tungumál eru lík, landfræðilega og veðurfarslega eru svæðin svipuð, opinber pjónusta mikil og faglegt starf áberandi, lög og reglur keimlíkar, auk pess sem lýðræði, jafnrétti og samfélagslegir pættir eru svipaðir (Larsen \& Neergaard 2007). Einkennandi fyrir norræna stjórnun eru opin samskipti, gagnrýni í hugsun, áhersla á lífsgæði, samfélag og umhyggju í bland við einstaklingshyggju. Norrænu löndin hafa grunngildi sem eru eftirsóknarverð fyrir próun skipulagsheilda eins og fram kemur í töflu 2 (Mandag Morgen 2005; Larsen \& Neergaard 2007).

Tafla 2. Grunngildi norrænnar stjórnunar. Framsetning höfunda, byggt á Mandag Morgen (2005) og Larsen og Neergaard (2007).

\begin{tabular}{l|l}
\hline Gildi & Stöðluð yfirlýsing / í daglegu tali nefnt \\
\hline Jafnrétti & Við berum umhyggju hvert fyrir öđru. \\
\hline Traust & Við treystum hvert öđru. \\
\hline Lítil valdafjarlægð & Við mætumst á jafnréttisgrundvelli. \\
\hline Samvinna & Við viljum hafa alla með. \\
\hline Sveigjanleiki & Við lögum okkur að ađstæðum. \\
\hline Umhverfisvitund & Við hugsum um náttúruna í dag og á morgun. \\
\hline Vinnusiðferði & Vinnan proskar okkur. \\
\hline Fagurfræði & Við kunnum að meta stílhreint og einfalt tjáningarform. \\
\hline
\end{tabular}


Norðurlöndin hafa ekki einkarétt á pessum gildum en pað er samsetning peirra sem skapar sérkennin. Í nútímavelferðarpjóðfélagi á Norðurlöndum er almennt metið hærra að hafa gott jafnvægi milli starfs og einkalífs og frítíminn er metinn til lífsgæða í meiri mæli en áður (Lund \& Reich 2013). Skandinavíska leiðin er af sumum talin stjórnunarstíll framtíðarinnar og hefur um árabil notið athygli frá umheiminum (Eriksen, Kruse \& Larsen 2006). Tvö meginatriði einkenna norrænan stjórnunarstíl; annars vegar er stjórnunarformið mótað af sameiginlegum ferlum í stofnuninni en ekki eingöngu af persónulegum stíl eða hegðun stjórnandans og hins vegar að starfsmenn eru virkir og taka að sér ábyrgð (Sørensen 2015). Sanngirni í verkferlum og skilvirk samskiptamynstur hvetja til fjölbreytni skoðana sem eykur gæði ákvarðana (Larsen o.fl. 2015; Sørensen 2015; Andersen \& Pors 2014). Pessi stjórnunarstíll hvetur til nýsköpunar og framleiðni í pekkingarfyrirtækjum af pví að stjórnun byggist á pví að styrkja starfsmenn, valdefla og hvetja pá til að taka ábyrgð. Í pví felst áhersla á hvatningu, að hafa alla með og deila pekkingu, að umgangast aðra með virðingu, hafa skýr markmið og gildi frekar en að nota eftirlit og skipanir.

Rannsóknin Nordisk Lys sem stýrt var af Larsen og Neergaard (2007) varpar ljósi á pað sem norrænu löndin, Svípjóð, Danmörk, Finnland og Noregur eiga sameiginlegt en jafnframt var fjallað um sérkenni pjóðanna. Í rannsókninni kemur fram að form og ferlar norrænnar forystu eru krefjandi fyrir stjórnendur og mikilvægt er að halda góðum tengslum við starfsmenn. Peir purfa að upplifa að peir séu meðeigendur verkefna af pví að peir eru bæði sjálfstæðir og faglega hæfir. Detta pýðir að pað koma auðveldlega upp ágreiningsefni ef væntingar eru ekki uppfylltar. Norræn forysta einkennist af löngum ákvarðanatökuferlum með mörgum fundum og pátttakendum sem getur pýtt að enginn tekur ábyrgð eða engar ákvarðanir eru teknar. Фаð er erfitt að taka óvinsælar og ópægilegar ákvarðanir pegar svo margir hafa aðkomu að ferlinu (Larsen \& Neergaard 2007).

Vinnustaðamenning mótast af sannfæringu, sameiginlegum gildum og sameiginlegum skilningi á pví hvernig hlutir eru gerðir (Armstrong 2014). Sannfæring verður til út frá reynslu í lífinu, ígildi reglu sem ekki parf að sannprófa (van Hauen, Kastberg \& Soden 2008). Til að breyta sannfæringu parf að skapa aðstæður par sem fólk sér möguleika frekar en hindranir. Menning á vinnustað hefur mikil áhrif og nauðsynlegt að taka tillit til hennar pegar unnið er að próun skipulagsheilda og skilja kraftinn sem felst í samspili fólks, ólíkum skoðunum, gildum, venjum og aðstæðum (Solsø \& Thorup 2015).

Larsen o.fl. (2015) fjalla um norræna stjórnun í samanburði við önnur lönd í greininni New Nordic Leadership - fair ledelse og strategi. Greinin byggir á gögnum úr alpjóðlegu rannsókninni The GLOBE Study (House o.fl. 2004) i samanburði við norrænar vinnustaðarannsóknir. Peir segja skandinavíska stjórnun og sérstaklega danska stjórnun skilvirka og ýta undir velgengni fyrirtækis. Hún einkennist af lítilli valdafjarlægð, mikilli samábyrgð í nýtingu auðlinda sem er samtvinnuð hugsjónafrelsi og jafnrétti kynjanna. Auk pess kom fram í rannsókninni að vinnustaðamenningin er mótuð af samræðum og stuttum boðleiðum á milli starfsmanna og stjórnenda og fjölbreytileikinn í norrænum stjórnunarstíl skapar árangursríkar stefnumarkandi lausnir og starfsánægju (Larsen o.fl. 2015).

Í danskri vinnustaðamenningu er mikil áhersla á samvinnu og sanngirni með tilliti 
til verkaskiptingar og dreifingu auðlinda (Larsen \& Neergaard 2007). Í Danmörku hafa stjórnvöld sett fram viðmið sem kallast Samkomulag um traust (Social- og indenrigsministeriet 2013). Áherslan er á að einfalda boðleiðir og ferla og færa valdið nær borgurunum. Jafnframt að nýta auðlindir með hagkvæmum hætti og veita pjónustu samkvæmt löggjöf.

Í greininni Íslensk vinnustaðamenning - Skýr og markviss stefna en skortur á samhæfingu og sampættingu kemur fram að íslenskar skipulagsheildir hafa skýra og markvissa stefnu sem starfsmenn eru tilbúnir að fylgja. En að betur purfi að sinna sampættingu og samhæfingu með pví að skilgreina ferla og samstarfsfleti á milli starfseininga. Vísbendingar eru um að sameiginleg gildi skorti og lítill vilji sé til breytinga (Gylfi Dalmann Aðalsteinsson Dórhallur Örn Guðlaugsson \& Ester Rós Gústavsdóttir 2010).

Hæfileikarnir til að lesa í aðstæður, nýta fyrri reynslu og skilja kraftinn sem felst 1 samspili fólks og aðstæðna eru mikilvægustu færnipættir í velgengni stjórnenda (Solsø \& Thorup 2015). Dað ber að líta á frávik sem tækifæri en ekki sem vandamál, af pví að pegar öllu er á botninn hvolft pá eru pað oft slík atvik sem hafa lykiláhrif í breytingaferli og skapa ný og óvænt tækifæri. Mikil próun hefur verið í breytingastjórnun undanfarin ár og nútímastjórnendur líta til samspils gilda, vinnustaðamenningar og umhverfis í tengslum við breytingaferli. Lögð er áhersla á að skilja aðstæður fyrirtækja og fólks, tengsl við umhverfið og áhrifapætti breytinga; samsetningu skipulags, menningu, pekkingu og lærdóm, stjórnunarhegðun, völd og pólitík (Burnes 2014). Upplýsingamiðlun er lykilatriði pegar breytingar eiga sér stað. „Viden og insigt er den korteste vej til dit mål“ segja van Hauen o.fl. (2008) sem í lauslegri pýðingu merkir að pekking og innsæi er stysta leiðin til árangurs.

Til að viðhalda góðri menningu á vinnustað purfa starfsmenn að upplifa ánægju í starfi. Í starfsánægju felast peir pættir sem hafa áhrif á líðan og parfir; svo sem möguleg starfspróun, ábyrgð, innihald starfsins, markmið, endurgjöf, sanngirni og hvatning. (Larsen og Neergaard 2007; Armstrong 2014). Upplifun og skynjun starfsfólks í pekkingarfyrirtækjum hefur áhrif á frammistöðu pess og starfsánægju. Đað kýs skýr markmið en mikið sjálfstæði í vali á leiðum að markmiðunum par sem pað nýtir tengslanet sitt og fyrri reynslu til að afla nýrrar pekkingar (Correia \& van Dierendonck 2010). Starfsánægja getur haft áhrif á árangur og árangur getur haft áhrif á starfsánægju og verið hvati. Ef starfsmaður hefur möguleika á að ná árangri pá mun pað hafa í för með sér hvatningu og starfsánægju.

Fræðimenn og sérfræðingar halda pví fram að norrænt stjórnunarlíkan verði eftirsóknarvert í framtíðinni, sérstaklega vegna fjölbreytileikans og möguleika á að aðlaga líkanið að mismunandi menningu, hefðum og samfélagslegum gildum (Velstandsgruppen og Mandag Morgen 2015).

\subsection{Opinber stjórnun og starfsumhverfi}

Á Norðurlöndunum er opinbera stjórnkerfið stórt, mikil áhersla er lögð á stjórnun á opinbera vinnumarkaðnum og gerðar hafa verið margar rannsóknir og skrifaðar fræðibækur sem skýra flókið samspil í opinberri stjórnun (Dahl \& Søholm 2012; Anderson \& Pors 2014; Solsø \& Thorup 2015; Sørensen 2015). 
Stjórnun ríkis og sveitarfélaga og stjórnun einkafyrirtækja byggir að mestu á sama kjarna pó að samspil kunni að vera flóknara í opinbera kerfinu par sem taka parf tillit til pólitískra afla. Helsti munur felst í arðsemiskröfu og ólíku mati á árangri par sem fjárhagslegur ágóði er mikilvægasta virðið á almennum markaði en hjá hinu opinbera snýst árangur um að veita pjónustu sem tekur mið af pörfum íbúa og samfélags. Klausen (2001) bendir á fjögur meginatriði sem mynda ramma um opinbert starfsumhverfi.

- Pólitísk stjórnun og starfsumhverfi einkennist af pví að ákvarðanir eru teknar af stjórnvöldum sem hafa lýðræðislegt umboð og skyldur.

- Stjórnun er kerfisbundin innan sérstaks lagaramma sem er pröngt skilgreindur í verkefnum og fjármálum.

- Djónustuskyldur eru miklar par sem hagsmunir heildarinnar eru hafðir að leiðarljósi.

- Viðfangsefnin eru margpætt og flókin par sem markmið geta verið óskýr en tryggja parf að almenningur njóti sanngirni.

Dahl og Søholm (2012) gerðu rannsókn meðal 15 opinberra stofnana ríkis og sveitarfélaga í Danmörku. Dar eru kynntir átta sérstakir færnipættir sem stjórnendur purfa að hafa til að ná góðum árangri í opinberri stjórnun eins og sjá má á mynd 2.

Mynd 2. Átta mikilvægir færnipættir opinberra stjórnenda. Framsetning höfunda, byggt á Dahl og Søholm (2012)

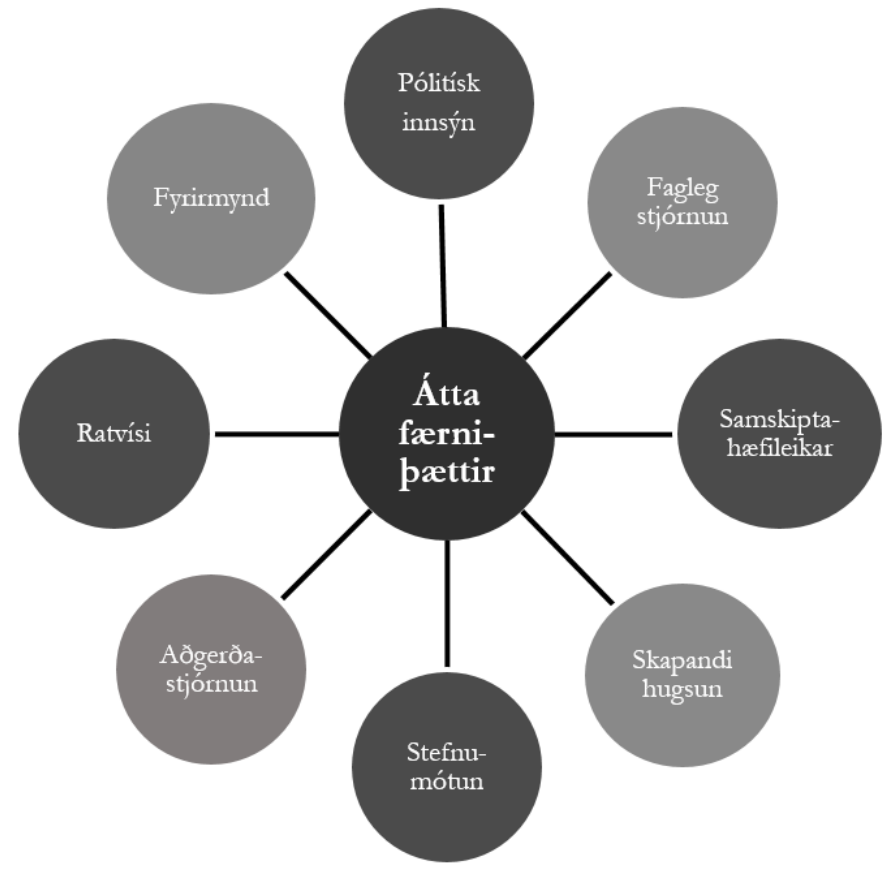


Margir pessara færnipátta eru mikilvægir fyrir alla stjórnendur. Баð eru sérstaklega pættirnir pólitísk innsýn og ratvísi (d. navigere) á opinberum vettvangi sem skera sig frá almennri stjórnun. Í kenningum Webers felst að vald skiptist í prjár tegundir; pað er regluvald, hefðarvald og náðarvald (van Wright 2003). Í lýðræðisríkjum ríkir regluvald og kröfur um skjalfestar upplýsingar aukast stöðugt par sem krafist er gegnsæis og jafnræðis. Í greininni Lýdraðisleg ábyrgð og rekstarform stjörnsýslu kemur fram að til að takast á við flókin verkefni í óvissu umhverfi bera stofnanir ábyrgð á pví að pörfum íbúa sé sinnt og til pess parf pólitíska forystu (Gunnar Helgi Kristinsson 2007). Skrifræði er hluti af vinnuumhverfi opinberra starfsmanna. Í skrifræðisstjórnsýslu hefur æðsti yfirmaður mikið vald yfir stjórnsýslunni sem undir hann heyrir og yfir starfsmönnum sem hann stýrir (Gunnar Helgi Kristinsson 2007). Í pví felst að æðstu yfirmenn fela öðrum umsjón ákveðinna verkefna og framselja valdið til að leysa verkefnin. Yfirvaldið gerir kröfu um hlýðni við lög, reglur og fyrirmæli sem gefin eru. Vaxandi efasemda gætir um hið lóðrétta form skrifræðis og til merkis um pað er að oftar eru sett viðmið um starfsemina par sem gerðar eru kröfur um árangur frekar en boðvaldi sé beitt (Gunnar Helgi Kristinsson 2007). Í opinberum stofnunum er pörf fyrir stjórnendur sem kunna á regluveldi og pekkja pólitískar leikreglur en einnig er mikilvægt að hafa sterka leiðtoga sem vinna með starfsfólkinu og íbúunum. Til staðar parf að vera sveigjanleiki og fjölbreytileiki og stjórnandi parf að vera meðvitaður um allar leiðir hagsmunaaðila til að koma skoðunum og upplýsingum á framfæri, sumt kemur að ofan, annað frá hlið eða að neðan, vegna pess að allir hafa jafnmikil áhrif á ákvarðanir í lýðræðispjóðfélagi (Dahl \& Søholm 2012).

Opinber stjórnun einkennist af flóknu samspili par sem athygli parf að vera samtímis á innri verkferlum stofnunar og á notendum pjónustunnar sem eru ávallt í brennidepli. раð er mikilvægt að rata í flóknu kerfi par sem stjórnunarformið byggir á að hugsa um parfir stofnunarinnar og átta sig á flóknu samspili fólks með hæfilegri blöndu af pví sem er fyrirsjáanlegt og ófyrirsjáanlegt (Solsø \& Thorup 2015). Forstöðumaður ber ábyrgð á að allir pekki hlutverk sitt (Dahl \& Søholm 2012). Algeng verkefni opinberra stjórnenda snúa að rekstri, ákvarðanatöku, upplýsingagjöf og samskiptum. Samkvæmt danskri rannsókn um próun stjórnendastarfsins fólst starfið fyrir 30 árum í pví að vera góður í skrifræði og uppfylla skilyrði um skjalfestar upplýsingar (Ejersbo \& Greve 2014). Í lok seinustu aldar jókst áhersla á árangursdrifna stjórnun og stjórnendur fengu meiri ábyrgð. Á fyrsta áratug pessarar aldar færðist áherslan frá föstum reglum yfir í sveigjanlegri viðmið. Megintilgangurinn var pá að skapa enn meiri árangur, efla samstarf og auka sýnileika gagnvart borgurunum með markvissari miðlun upplýsinga. Enn er mikil áhersla á árangur ásamt áherslu á gæði pjónustunnar, fjárhagslegt aðhald og pólitískan sýnileika gagnvart íbúum (Ejersbo \& Greve 2014).

Eftirlit er hluti af ákvarðanahlutverkinu. Ráðherra eða yfirmaður sveitarfélags ber ábyrgð á eftirliti og hefur úrskurðarvald hjá opinberum stofnunum. Ráðherra og ráðuneyti eru helstu frumkvöðlar lagasetninga og ráða mestu um hvernig pau próast (Gunnar Helgi Kristinsson 2007). Kjörnir fulltrúar almennings hafa síðan ákvörðunarvald og bera ábyrgð á úthlutun fjármagns til verkefna. Фаð er pó alltaf almenningur sem hefur síðasta orðið með kosningum í lýðræðisríkjum par sem kjósendur velja sína fulltrúa. 
Úthlutun fjármagns er stýrt af kjörnum fulltrúum ríkisvaldsins og sveitarfélaganna með fjárlögum og fjárhagsáætlunum. Opinberir stjórnendur starfa eftir pessum fjárhagsáætlunum (fjárlögum) samkvæmt stefnu sem pólitískir fulltrúar setja hverju sinni, gera fjárhagsáætlanir, fylgjast með flæði fjármagns, sundurliða upplýsingar og skila með formlegum hætti. Strangar reglur gilda um meðferð opinbers fjármagns og tryggja parf gegnsæi og gæta pess að nota fjármagn með hagkvæmum hætti, forðast sóun og sýna fram á góðan árangur í rekstri. Stjórnendur hafa oft lítil áhrif á úthlutun fjármagns (Gunnar Helgi Kristinsson 2007).

Stjórnunaraðferðin New Public Management (NPM) hefur verið vinsæl í opinberri stjórnun. Um er að ræða stjórnunar- og markaðslíkan með áherslu á árangursstjórnun, samkeppnishæfni, valdeflingu og öflugt tengslanet (Renison 2000). Gæðamenning, aðlögunarhæfni og frumkvæði eru mikils metnir eiginleikar innan starfsmannahópsins. prátt fyrir að NPM hafi notið mikilla vinsælda pá bendir Renison á að aðferðin var ekki tekin beint upp á Norðurlöndum heldur má segja að hún hafi verið aðlöguð að norrænu líkani par sem tekið er tillit til félagslegra pátta á Norðurlöndum. Talið er mikilvægt að samtvinna eftirlit og traust frekar en að líta á pessa pætti sem andstæða póla. Með auknu trausti og ábyrgð á eigin verkefnum er hægt að minnka formlegt eftirlit sem getur skapað fjárhagslegan ávinning og aukið starfsánægju (Svendsen 2015).

Á Íslandi var tekin upp samræmd árangursstjórnun í ríkisrekstri árið 1996. Lykilbættir árangursstjórnunar eru stefna, forgangsröðun verkefna, áætlanagerð, skilgreining mælikvarða og markviss eftirfylgni af hálfu ráðuneyta (Ríkisendurskoðun 2003). Í úttektinni Nádist árangur? Úttekt á árangursstjórnun i ríkisrekstri sem gerð var af Ríkisendurskoðun (2003) kemur fram að árangursstjórnun var skammt á veg komin hjá stofnunum ríkisins á peim tíma en pað var mat Ríkisendurskoðunar að árangursstjórnun gæti orðið mikilvægt stjórntæki í ríkisrekstrinum. Helstu ástæður pess að innleiðing breytinga gekk hægt var að stofnanir töldu sig ekki fá nægilega skýr skilaboð um að bæta árangur sinn og skilvirkni. Í úttektinni kemur fram að ráðuneytin hafi almennt ekki birt heildstæða langtímastefnu sem fyrirmynd stefnu og markmiða stofnana. Einnig kom fram að útfærsla árangursstjórnunar hérlendis hafi ekki hentað stofnunum nægilega vel og bent á að langan tíma taki alla jafna að innleiða breytingar sem krefjast breytts hugarfars (Ríkisendurskoðun, 2003). Talið er að stjórntækið geti hentað í ríkisrekstri; svo fremi að stjórnvöld leggi áherslu á mikilvægi árangursstjórnunar. Í skýrslu Fjármálaráduneytisins frá árinu 2011, Staða árangursstjórnunar í opinberum rekstri kemur fram að betur megi gera með tilliti til samræmingar á verklagi á milli ráðuneyta og skapa betri heildarnálgun. Síðan árangursstjórnun var fyrst innleidd hafi mörgu verið áorkað hvað varðar innleiðingu nútímastjórnunaraðferða og hugsunarháttar (Fjármálaráðuneytið 2011). Einnig kom fram að ráðuneyti töldu að árangursstjórnunarsamningar gætu nýst sem stjórntæki til að efla samskipti, bæta pekkingu og auka eftirlit með starfsemi stofnana.

\section{3 Íslenskir stjórnendur}

Fáar rannsóknir hafa verið gerðar hérlendis á störfum opinberra stjórnenda í samanburði við starfsfélaga í öðrum löndum og beinast flestar rannsóknir að almennum 
vinnumarkaði par sem fyrirtæki eru rekin í hagnaðarskyni. Pegar íslenskur vinnumarkaður er skoðaður kemur fram að hann er svipaður og á öðrum Norðurlöndum með öflugt velferðarkerfi og sterk verkalýðsfélög. Hann sker sig samt úr að pví leyti að meiri áhersla er á einstaklingshyggju og sveigjanleika sem svipar frekar til breska og bandaríska vinnumarkaðarins (Árelía Guðmundsdóttir \& Jón Guðjónsson 2013).

Pau einkenni sem birtast í rannsóknum sýna að íslensk stjórnun einkennist af einstaklingshyggju, frumkvöðlahneigð, áræðni, óformlegum samskiptum, frelsi, hraða, frumleika og sveigjanleika. Íslenskir stjórnendur treysta lítið á formlegar reglur, treysta á eigin reynslu, eiga auðvelt með opin samskipti og telja gagnrýni og ágreining eðlilegan. Peir búa yfir seiglu (Ásta Dís Óladóttir \& Ragnheiður Jóhannesdóttir 2008; Árelía Guðmundsdóttir \& Jón Guðjónsson 2013; Gylfi Dalmann Aðalsteinsson, Svala Guðmundsdóttir \& Dórhallur Örn Guðlausson 2011). Greinin Íslenske pjódmenning i ljósi menningarvídda Hofstede styður að mestu framangreinda lýsingu en par kemur einnig fram að kynjamunur og valdafjarlægð eru lítil sem eru einkenni í samræmi við nágranna okkar á Norðurlöndum (Gylfi Dalmann Aðalsteinsson o.fl. 2011). Rannsókn frá 2009 leiddi einnig í ljós að íslenskir stjórnendur beita hefðbundnum norrænum leiðum; svo sem lýðræðislegum aðferðum og liðsvinnu í bland við aðrar pekktar stjórnunaraðferðir (Ingi Rúnar Eðvarðsson \& Guðmundur Kristján Óskarsson 2009).

Degar skoðuð eru verkefni íslenskra stjórnenda kemur fram í rannsókninni Starfsumhverfi ríkisstarfsmanna við aldabvörf að störf stjórnenda í opinberum stofnunum felast 1 skipulagningu og framkvæmd verkefna sem stjórnendum eru falin af par til bærum aðilum og unnin eru samkvæmt ákveðinni stefnu (Ómar H. Kristmundsson 1999). Par er verkefnum stjórnenda skipt í sjö meginflokka sem eru áætlanagerð, skipulagsvinna, starfsmannastjórnun, ákvarðanataka, samhæfing, upplýsingamiðlun og fjármálastjórnun. Í óbirtri rannsókn Dórunnar Kristínar Sigurðardóttur (2013), Madur er alltaf a leita lausna, kemur fram að mikill tími millistjórnenda í heilbrigðispjónustu á Íslandi fer í mannauðsmál og samskipti, að vera til staðar fyrir starfsfólkið en hafa á sama tíma yfirsýn yfir starfsemina, takast á við breytingar ásamt pví að vera góð fyrirmynd. Í rannsókn um próun stjórnendahæfni í litlum og meðalstórum fyrirtækjum kemur fram að mikill tími fer 1 a a sinna starfsmannamálum og mikilvægast er fyrir stjórnendur að búa yfir félagslegri færni og samskiptafærni. Minni áhersla er lögð á að stjórnendur búi yfir ýmsum öðrum hæfnipáttum; svo sem fjármálapekkingu, heildaryfirsýn og stefnumörkun (Harpa Björg Guðfinnsdóttir \& Inga Jóna Jónsdóttir 2005).

Degar skoðuð er ákvarðanataka skipulagsheilda hjá hinu opinbera (Ingi Rúnar Eðvarðsson \& Ása Líney Sigurðardóttir 2010) kemur í ljós að stjórnendur í opinberum stofnunum hafa minna umboð til ákvarðanatöku um stefnumarkandi atriði en stjórnendur í einkafyrirtækjum. Við ákvarðanatöku í stærri málum tekur ferlið lengri tíma hjá opinberum stofnunum en hjá einkaaðilum vegna pess að hafa parf samráð við marga aðila sem kallar á málamiðlanir. Einnig hefur löggjöf mikil áhrif og takmarkar ákvörðunarvald opinberra stjórnenda (Ingi Rúnar Eðvarðsson \& Ása Líney Sigurðardóttir 2010). 


\subsection{Danskir stjórnendur}

Einkennandi fyrir danska stjórnun er að starfsmenn eru virkir pátttakendur í ákvarðanatöku og hafa áhrif á vinnuumhverfið. Stjórnunarstíll er opinn, leyfilegt er að gagnrýna stjórnendur. Ábyrgð er dreifð og áhersla lögð á persónuleg samskipti, virðingu, hvetjandi leiðtogastíl og faglega færni. Stjórnendur eru óformlegir í samskiptum og treysta lítið á yfirmenn eða formfestu. Deir treysta eigin dómgreind og reynslu frekar en reglum, eru fljótir að taka ákvarðanir og setja langtímamarkmið (Larsen \& Neergaard 2007; Larsen o.fl. 2015; Bentzen 2015; Ásta Dís Óladóttir \& Ragnheiður Jóhannesdóttir 2008). Mismunur á væntingum og áherslum pegar kemur að pví að hvetja og styrkja starfsmenn hefur verið skoðaður. Баð kemur fram að í Danmörku skorar hvetjandi leiðtogastíll mjög hátt (House o.fl. 2004; Larsen o.fl. 2015). Í grein um Íslenska stjórnendur i norranum samanburd $i$ kemur fram að Danir eiga auðvelt með að treysta undirmönnum og treysta lítið á formfestu en hafa trú á eigin reynslu og pekkingu (Ásta Dís Óladóttir \& Ragnheiður Jóhannesdóttir 2008). Í greininni kemur fram að stjórnunarstíllinn er óformlegur og opinn með áherslu á persónuleg samskipti, kímnigáfu og samkeppni. Fyrirtæki eru lítil, frumkvæði mikið og áhersla á faglega hæfni. Í rannsókninni Nordisk Lys er stjórnun í Danmörku lýst pannig að valddreifing sé mikil, starfsmenn eru hafðir með í ráðum og bera ábyrgð. Starfsmenn geta haft áhrif á starfsemina, stjórnunarstill er opinn og andrúmsloft er afslappað. Danskir stjórnendur eru fljótir að taka ákvarðanir og leyfilegt er að ræða á opinskáan og gagnrýninn hátt við stjórnendur en á sama tíma er samkomulag um að stjórnandinn hafi seinasta orðið í ákvarðanatökuferli (Larsen \& Neergaard 2007).

Í rannsókninni De offentlige ledere og Tillidsaftalen - barrierer og drivkrafter eru verkefni opinberra stjórnenda skoðuð með tilliti til helstu drifkrafta og hindrana í opinberri stjórnun (Bentzen 2015). Helstu niðurstöður eru að opinberir stjórnendur í Danmörku eru sáttir við framsetningu á fjárhagsáætlunum en peim pykir skorta svigrúm til að færa fjármagn á milli tímabila. Mikilvægt er fyrir stjórnendur að vera pátttakendur í ákvarðanatökuferlum og flestir upplifa að peir geti komið mikilvægum málum á framfæri. Stjórnendur upplifa öryggi við skráningu gagna en betur mætti nýta pessi gögn til að auka gæði starfseminnar. Samskiptin á vinnustað eru góð og einkennast af virðingu og opnum skoðanaskiptum. Lög og reglugerðir eru stærsta hindrun opinberra stjórnenda og skrifræði pykir of mikið. Meirihluti stjórnenda telur að pá skorti hæfni til ákvarðanatöku, einföldunar á verkferlum og við hvatningu starfsmanna.

\section{Aðferðafræði}

Framkvæmd var rannsókn meðal stjórnenda í opinberri stjórnsýslu á Íslandi. Spurt var um starfsumhverfið, viðhorf stjórnenda og helstu hindranir í opinberri stjórnun; svo sem bakgrunn stjórnenda, fjárhagsleg skilyrði, skipulagsleg skilyrði, kröfur um skráningu, tengslanet, skrifræði, skilvirkni og færni. Opinber stjórnandi er skilgreindur sem stjórnandi sem vinnur hjá ríki eða sveitarfélagi og ber ábyrgð á starfsemi stofnunar eða deildar innan stofnunar, ber ábyrgð á fjármálum að hluta eða öllu leyti og hefur mannaforráð eða er í forsvari fyrir hóp starfsmanna. 
Spurningin sem lögð var fram í upphafi hljóðar svo: Geta opinberir stjórnendur á Íslandi lært af norrænum starfsfélögum varðandi stjórnun og forystu? Til afmörkunar á verkefninu eru settar fram nokkrar undirspurningar og í pessari grein er fjallað sérstaklega um verkefni og áherslur íslenskra stjórnenda í samanburði við danska stjórnendur.

Dönsk rannsókn, De offentlige ledere og Tillidsaftalen - barrierer og drivkrafter (Bentzen 2015), var notuð sem fyrirmynd. Send var vefkönnun til stjórnenda opinberra stofnana á Íslandi í gegnum forritið LimeSurvey. Netfanga var aflað með pví að skoða heimasíður stofnana, sveitarfélaga og ráðuneyta í júlí 2015. Við val á pátttakendum var ekki leitað netfanga millistjórnenda ef framkvæmdastjórn var kynnt á heimasíðu. Dar sem hópur opinberra stjórnenda á Íslandi er aðgengilegur pá var ekki valið úrtak heldur var könnunin send til allra opinberra stjórnenda í peim tilgangi að fá eins nákvæma svörun og mögulegt var. Samtals fundust netföng hjá 1.786 stjórnendum en pegar könnunin var send út kom í ljós að frá 101 netfangi kom sjálfvirkt svar um að pað væri ekki í notkun. Pátttaka í rannsókninni var viðunandi par sem 524 svara af 1.685 stjórnendum, eða 31\%. Vefkönnunin var opin á tímabilinu 16. september til 10. október 2015 og var hvatningarpóstur sendur pann 1. október til peirra sem ekki höfðu svarað á peim tíma. Skipting netfanga innan pýðis sést í töflu 3.

Tafla 3. Samsetning pýđis

\begin{tabular}{l|c|c}
\hline Innan hvaða starfssviðs er netfang & Fjöldi & Hlutfall i \% \\
\hline Heilbrigðispjónusta & 71 & 4 \\
\hline Menntun og menning & 434 & 25 \\
\hline Stjórnendur sveitarfélaga & 991 & 57 \\
\hline Stjórnendur ríkisstofnana & 190 & 11 \\
\hline Annað & 50 & 3 \\
\hline
\end{tabular}

Borin voru saman verkefni og viðhorf stjórnenda á Íslandi og í Danmörku. Samanburður á milli hópa er vandmeðfarinn. Hóparnir sem hér eru bornir saman eru ekki að öllu leyti sambærilegir prátt fyrir að í báðum tilfellum sé fjallað um opinbera stjórnendur í löndunum tveimur. Fjölmennasti hópur íslenska býðisins voru stjórnendur sveitarfélaga en í danska pýðinu voru stjórnendur með aðild að stéttarfélögum í pjónustugreinum, félagsráðgjöf og félagspjónustu fjölmennastir. Meginmunur rannsóknanna felst í pví að á Íslandi var viðhorfskönnun lögð fyrir alla opinbera stjórnendur sem starfa hjá ríki eða sveitarfélögum en danska viðhorfskönnunin var lögð fyrir úrtak stjórnenda í premur stéttarfélögum með jafnri skiptingu á milli félaganna (Bentzen 2015). Pá parf að hafa í huga að íslenskir stjórnendur búa að einhverju leyti við annað starfsumhverfi en danskir, til dæmis hafa ekki verið sett viðmið á Íslandi sem eru sambærileg við Samkomulagið um traust (Social- og indenrigsministeriet 2013). Đað hefur í för með sér að sumar spurningar í könnuninni hafa ekki sama vægi á Íslandi og í Danmörku. 


\section{Niðurstöður}

Rannsóknin sem eftirfarandi niðurstöður byggja á var lögð fyrir stjórnendur í september árið 2015 og lauk í október sama ár. Dönsk rannsókn var höfð sem fyrirmynd (Bentzen 2015). Bakgrunnur svarenda er mikilvægur páttur og gefur vísbendingar um samsetningu hópsins. Konur eru 57\% en 39\% karlar eins og fram kemur í töflu 4.

Tafla 4. Kynjahlutfall stjórnenda

\begin{tabular}{l|c|c}
\hline Kyn & Fjöldi svara & Hlutfall $\mathbf{i} \%$ \\
\hline Kona & 298 & 57 \\
\hline Karl & 204 & 39 \\
\hline Ekkert svar & 22 & 4 \\
\hline
\end{tabular}

Flestir svarendur starfa við menntun og menningu eða 55\% en að öðru leyti dreifist pátttaka á ýmis starfssvið, (tafla 5).

Tafla 5. Starfssvið

\begin{tabular}{l|c|c}
\hline Innan hvađa starfssviðs vinnur pú? & Fjöldi svara & Hlutfall i \% \\
\hline Félagspjónusta & 35 & 7 \\
\hline Heilbrigðisbjónusta & 29 & 6 \\
\hline Menntun og menning & 286 & 55 \\
\hline Fjármál og rekstur & 56 & 11 \\
\hline Annað & 109 & 21 \\
\hline Ekkert svar & 9 & 2 \\
\hline
\end{tabular}

Flestir stjórnendur eru komnir yfir miðjan aldur. Í töflu 6 kemur fram að flestir stjórnendur, tæplega 60\%, eru meira en 50 ára. Eingöngu 2\% eru innan við 30 ára.

Tafla 6. Aldur stjórnenda

\begin{tabular}{l|c|c}
\hline Aldur & Fjöldi svara & Hlutfall í \% \\
\hline 30 ára eđa yngri & 9 & 2 \\
\hline $31-40$ ára & 47 & 9 \\
\hline $41-50$ ára & 150 & 29 \\
\hline $51-60$ ára & 212 & 40 \\
\hline Eldri en 60 ára & 97 & 19 \\
\hline Ekkert svar & 9 & 2 \\
\hline
\end{tabular}

pegar skoðað er hversu lengi stjórnendur hafa verið í núverandi starfi kemur í ljós að einungis 14\% svarenda hafa verið í núverandi starfi í minna en tvö ár en ríflega helmingur stjórnenda hafa verið í núverandi starfi lengur en 8 ár og hafa 38\% starfað lengur en 10 ár, samanber töflu 7. 
Tafla 7. Starfsaldur

\begin{tabular}{l|l|l}
\hline Hversu lengi hefur bú verið í núverandi starfi? & Fjöldi svara & Hlutfall í \% \\
\hline Minna en 2 ár & 71 & 14 \\
\hline 2-4 ár & 94 & 18 \\
\hline $5-7$ ár & 79 & 15 \\
\hline $8-10$ ár & 76 & 15 \\
\hline Lengur en 10 ár & 201 & 38 \\
\hline Ekkert svar & 3 & 1 \\
\hline
\end{tabular}

Degar tekin eru saman svör úr pessum fjórum bakgrunnsspurningum kemur í ljós að ríflega helmingur peirra sem svara eru konur, oftast eru svarendur yfir fimmtugt, flestir starfa við menntun eða menningu og hafa jafnframt verið lengi i núverandi starfi.

\subsection{Fjárhagsleg skilyrđi}

Íslenskir stjórnendur eru jákvæðir gagnvart fjárhagslegum skilyrðum, bæði hvað varðar upplýsingar sem parf að skila, sundurliðun og hvernig verkefnaálag dreifist yfir árið. Nokkuð skortir á að peir geti ráðstafað fjármagni með peim hætti sem peir kjósa helst og peir upplifa að fjármagn skorti fyrir pá pjónustu sem peim er ætlað að veita (sjá mynd 3).

\section{Mynd 3. Fjárhagsleg rekstrarskilyrði}

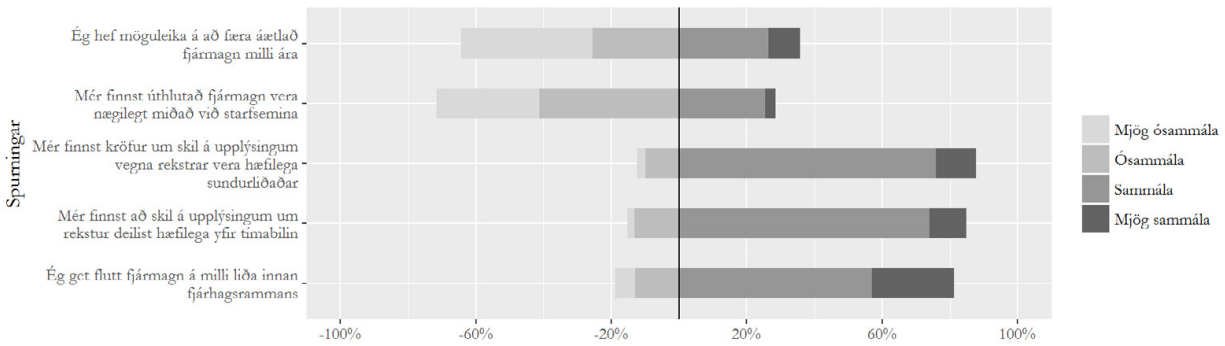

Fjármál eru veigamikill páttur í starfseminni. Stjórnendur eru sáttir við atriði sem snúa að pví hvernig upplýsingar um reksturinn eru sundurliðaðar, hvernig skil á upplýsingum dreifast yfir árið og að peir geta flutt fjármagn á milli liða innan fjárhagsrammans. Hins vegar telja eingöngu 35\% stjórnenda að peir geti flutt fjármagn á milli ára og eingöngu $30 \%$ stjórnenda telja fjármagn nægilegt miðað við starfsemina.

Degar borin eru saman svör íslenskra og danskra stjórnenda kemur í ljós að upplifun stjórnenda er svipuð, pó kemur í ljós að fleiri danskir stjórnendur upplifa að úthlutað fjármagn til starfseminnar sé hæfilegt miðað við starfsemina og meirihluti peirra telur að peir geti flutt fjármagn á milli tímabila. 


\subsection{Skipulagsleg skilyrði}

Stjórnendur eru almennt ánægðir með skipulagsleg skilyrði í vinnunni eins og fram kemur á mynd 4 . Vert er að vekja athygli á að $22 \%$ stjórnenda telja sig ekki fá nægan tíma til umhugsunar í ákvarðanatökuferlum. Detta vekur upp spurningar um orsakir; er pað vegna pess að upplýsingar berast of seint, vegna tímaskorts eða liggja aðrar ástæður par að baki?

\section{Mynd 4. Vinnuskipulag}

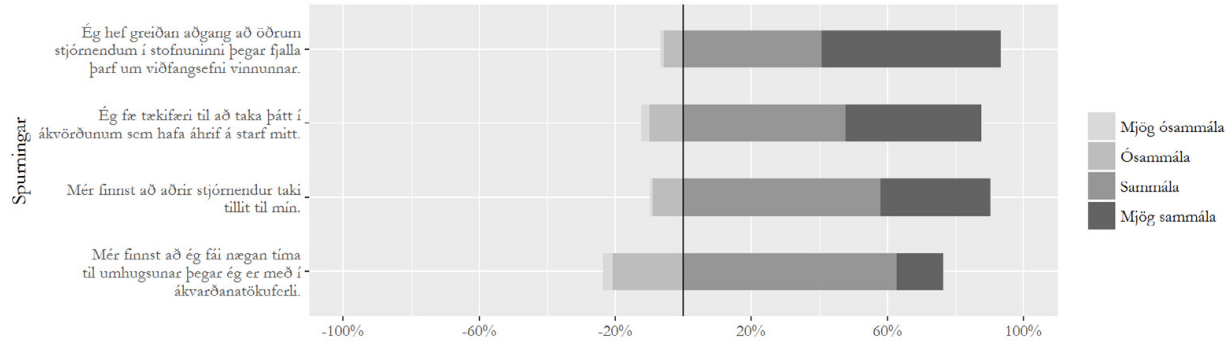

Pegar skoðaðar eru fullyrðingar um skipulagsleg skilyrði má sjá að stjórnendur eru í meginatriðum ánægðir eða mjög ánægðir með ríkjandi fyrirkomulag.

Samanburður við danska stjórnendur leiðir í ljós að vinnuskilyrði í löndunum tveimur virðast vera mjög lík, bæði hvað varðar verklag á vinnustað og mikilvægi pessara skilyrða fyrir stjórnendur.

\subsection{Skrifræði}

Allir stjórnendur voru spurðir um pað hvort peir teldu ákveðna verkferla á vinnustaðnum vera ónauðsynlegt skrifræði. Ríflega helmingur íslenskra stjórnenda, 272 einstaklingar (52\%), telur svo ekki vera. Sá hópur sem telur að pað sé of mikið af ónauðsynlegu skrifræði, eða 209 einstaklingar (40\%), fékk framhaldsspurningar um hvað hindrar breytingar í peim tilgangi að einfalda verkferla (mynd 5).

\section{Mynd 5. Hindranir fyrir einföldun verkferla}

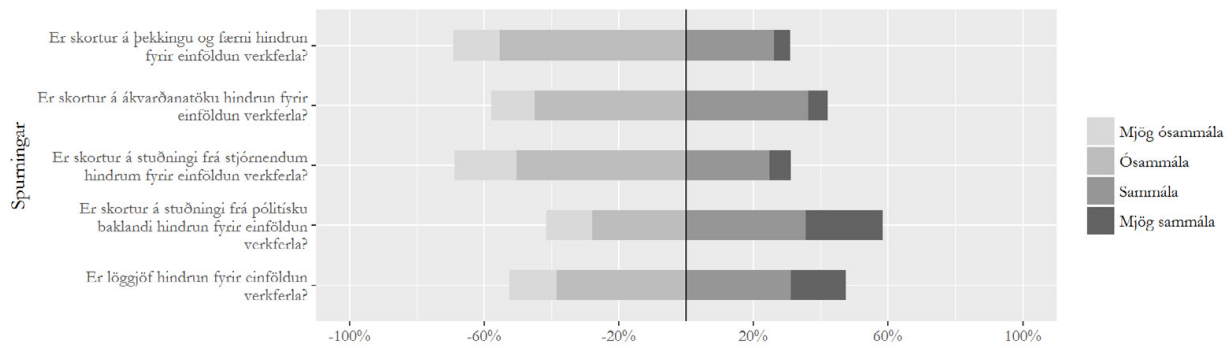


Af peim stjórnendum sem telja sig purfa að sinna ónauðsynlegu skrifræði telur ríflega helmingur skort á stuðningi frá pólitísku baklandi vera helstu hindrun fyrir einföldun verkferla. Enn fremur telja 40\% löggjöf og skort á ákvarðanatöku vera hindranir.

Mjög mikill munur kemur fram í spurningaflokki um skrifræði, pegar horft er til samanburðar íslenskra og danskra stjórnenda. Mun fleiri danskir stjórnendur (63\%) telja að pað séu vinnuferlar á vinnustaðnum sem flokka má sem skrifræði.

\subsection{Tengslanet}

Spurt var um tengsl og samskipti við aðra stjórnendur og samstarfsfólk. Mikill meirihluti íslenskra stjórnenda, eða ríflega 85\%, eru sammála eða mjög sammála fullyrðingum um að tengslanet á vinnustað sé gott, að samskipti við yfirmenn séu á jafnréttisgrundvelli og 87\% eru sammála eða mjög sammála pví að traust ríki almennt í samskiptum, (mynd 6).

\section{Mynd 6. Tengslanet}

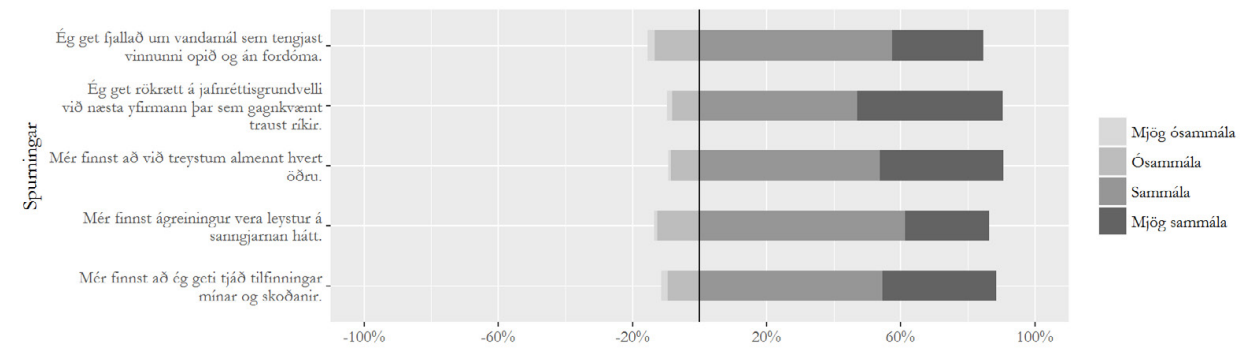

Fram kemur að lítill hluti stjórnenda eða 15\% eru ósammála eða mjög ósammála pví að peir geti fjallað um vandamál tengd vinnunni opið og án fordóma og 13\% stjórnenda finnst ágreiningur ekki vera leystur á sanngjarnan hátt.

Í pessum spurningaflokki um tengslanet á vinnustað eru niðurstöður keimlíkar á milli landanna tveggja.

\subsection{Skjalfestar upplýsingar}

Stjórnendur voru spurðir um kröfur sem gerðar eru um skjalfestar upplýsingar og peir beðnir um að meta fullyrðingarnar út frá pví hversu miklar kröfur eru gerðar á vinnustaðnum til skráningar á gögnum og meðferð gagna. Deim finnst kröfur um skjalfestar upplýsingar sanngjarnar en bæta má árangur eins og fram kemur á mynd 7. 


\section{Mynd 7. Kröfur um skjalfestar upplýsingar á vinnustað}

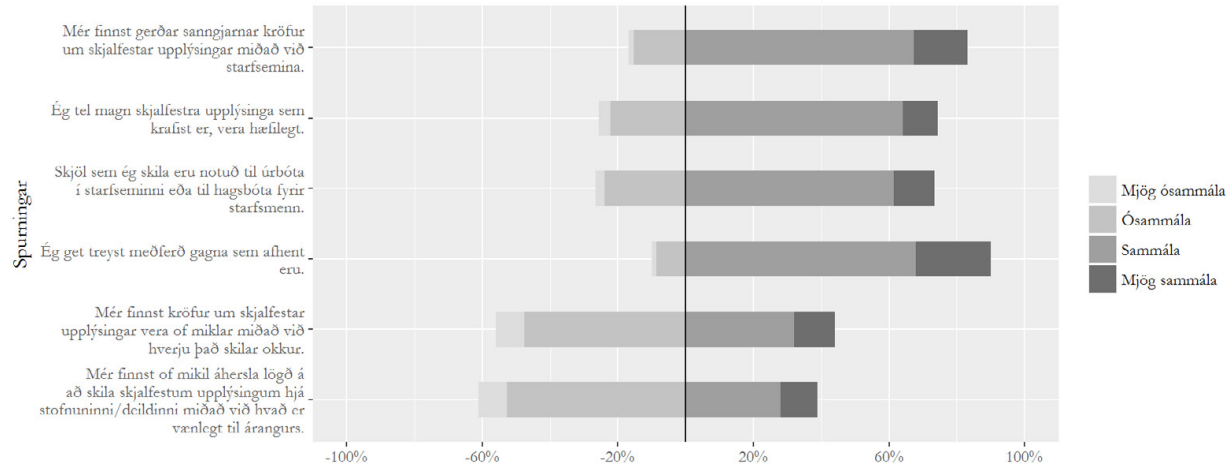

Á mynd 7 kemur fram að mikið traust ríkir gagnvart meðferð á skjalfestum upplýsingum. Fram kemur að 84\% stjórnenda eru mjög sammála eða sammála fullyrðingunni um traust við meðferð gagna. Pá telur $70 \%$ svarenda magn skjalfestra upplýsinga vera hæfilegt og 66\% telja upplýsingarnar vera notaðar til úrbóta í starfseminni. Degar spurt var hvort skjalfestar upplýsingar skili úrbótum í starfsemi eigin stofnunar pá kom fram að $40 \%$ stjórnenda er sammála eða mjög sammála pví að kröfur séu of miklar og 35\% telja of mikla áherslu lagða á skjalfestar upplýsingar miðað við hvað er vænlegt til árangurs í stofnuninni.

Í pessum spurningaflokki var spurt um traust til gagna sem afhent eru og í báðum löndunum kemur fram að langstærsti hópur stjórnenda telur að peir geti treyst meðferð gagna. Íslenskir stjórnendur telja flestir skráningu vera notaða til úrbóta í starfseminni (66\%) á meðan 43\% danskra stjórnenda telja svo vera.

\subsection{Skilvirkni}

Degar spurt er um skilvirkni eða árangur á vinnustað kemur í ljós að 458 stjórnendur (87\%) telja tækifæri felast í aukinni skilvirkni. Í spurningaflokknum um hindranir fyrir skilvirkni á vinnustaðnum kemur fram að um priðjungur telur pekkingu og færni, stuðning frá stjórnendum og löggjöf vera mikla eða mjög mikla hindrun fyrir aukinni skilvirkni á vinnustaðnum og 43\% telja lítinn stuðning frá pólitísku baklandi vera hindrun.

Degar spurt er um áhrif stjórnenda á hindranir pá telja flestir að peir hafi afar takmörkuð áhrif á hindranirnar sem spurt er um. Áberandi er að stjórnendur telja sig hafa mjög lítil áhrif á pólitískt bakland og löggjöf pegar kemur að pví að bæta árangur í stofnunum en pað kemur líka á óvart að peir telji sig hafa lítil áhrif á innra starfsumhverfi, sjá mynd 8 . 


\section{Mynd 8. Hindranir fyrir skilvirkni}

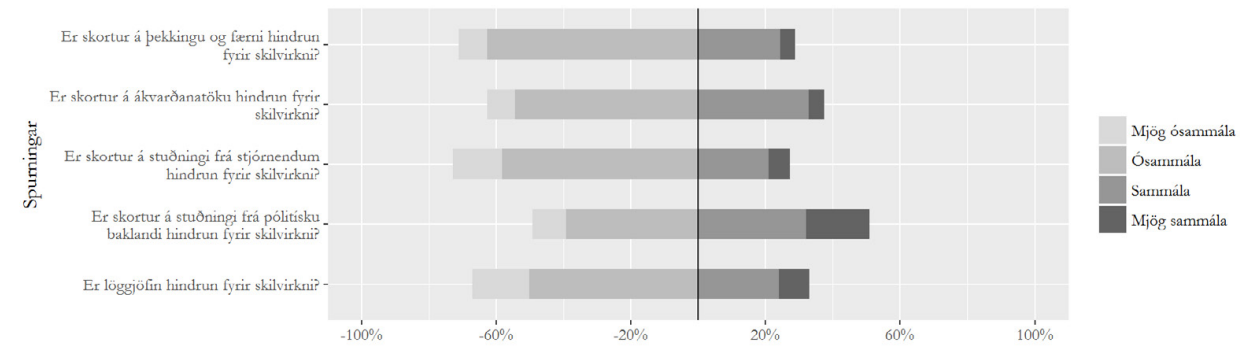

Danskir stjórnendur telja hindranir varðandi skilvirkni vera meiri en íslenskir, ef frá er talinn stuðningur frá pólitísku baklandi par sem svipaður fjöldi stjórnenda í báðum löndum telur hann vera hindrun. Pegar skoðað er hvaða áhrif stjórnendur hafa á pessa sömu pætti kemur í ljós að par er verulegur munur par sem danskir stjórnendur hafa mun meiri áhrif á hindranir er varða pekkingu og færni og sömu sögu er að segja um áhrif á ákvarðanatöku. Áhrif á stuðning frá yfirstjórn eru svipuð í báðum löndum en áhrif á stuðning frá pólitísku baklandi og áhrif á löggjöf er minni hjá íslenskum stjórnendum en dönskum.

\subsection{Færni}

Stjórnendur voru spurðir um hvaða færni peir telja sig purfa að bæta til að uppfylla kröfur sem gerðar eru á peirra starfssviði, pegar litið er til framtíðar. Talin voru upp 15 atriði í fjölvalsspurningu. Mynd 9 sýnir hvaða fimm færnipætti stjórnendum fannst mikilvægast að bæta til að uppfylla kröfur sem peir telja að gerðar verði til peirra í framtíðinni.

\section{Mynd 9. Færni til framtíđar}

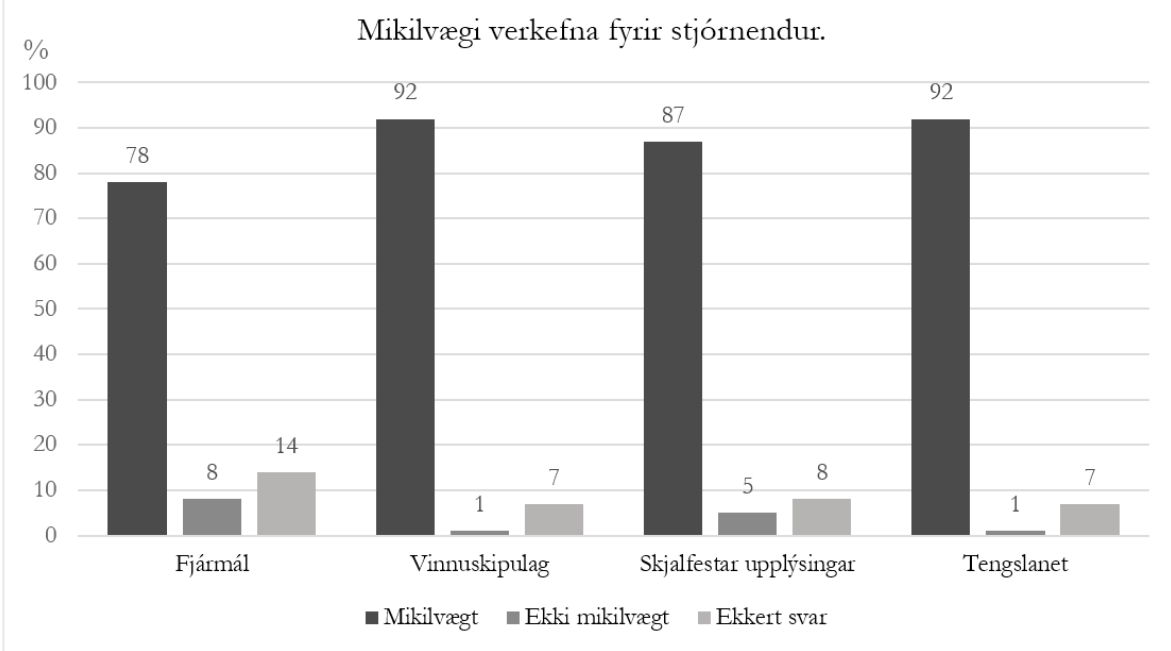


Aukin færni er mikilvæg að mati stjórnenda og greinilegt að gæðastjórnun er áhersluatriði sem margir stjórnendur telja að peir purfi að auka færni sína í. Peir telja einnig mikilvægt að setja fram langtímaáætlanir og skýra framtíðarsýn og styðja starfsfólkið og hvetja.

Degar pörf stjórnenda fyrir færni er skoðuð pá eru stjórnendur í báđum löndum sammála um að peir purfi að bæta færni sína í að vinna með markvissum hætti að gæðastarfi og að setja fram skýra framtíðarsýn. Til viðbótar telja danskir stjórnendur mikilvægt að bæta pjónustu í samræmi við óskir og væntingar notenda og íslenskir stjórnendur hafa áhuga á færni sem stuðlar að hvatningu og eflingu starfsfólks.

3.8 Helstu einkenni íslenskrar stjórnunar

Helstu niðurstöður rannsóknarinnar sýna að opinberir stjórnendur á Íslandi eru frekar ánægðir með starfsumhverfið pegar á heildina er litið og telja verkefnin sem peim eru falin vera mikilvæg. Раð byggir á traustu tengslaneti, góðum samskiptum og almennri sátt við dagleg verkefni par sem stjórnendur upplifa sanngjarnar kröfur. Stjórnendur upplifa góð tengsl á vinnustað við aðra starfsmenn, við aðra stjórnendur og traust í samskiptum, samanber mynd 10.

\section{Mynd 10. Mikilvæg verkefni stjórnenda}

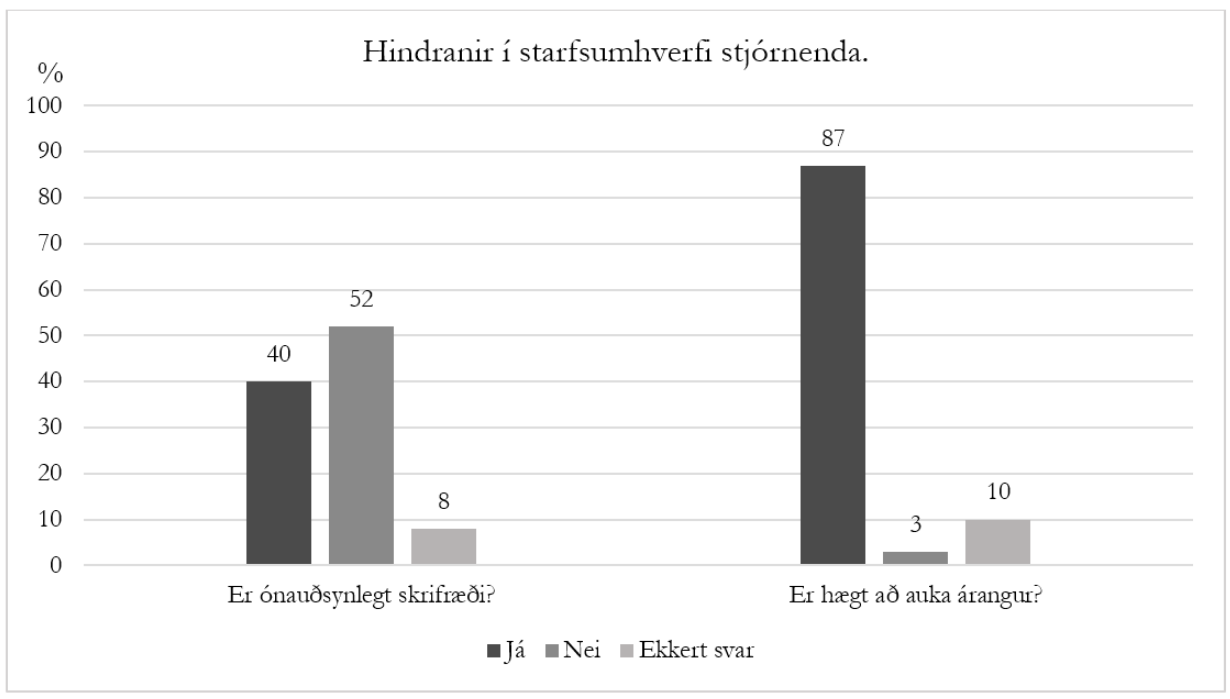

Niðurstöðurnar sýna að meirihluti stjórnenda telur skrifræði ekki vera hindrun í starfsumhverfinu en hins vegar telur yfirgnæfandi meirihluti stjórnenda að pað mætti bæta árangur á vinnustaðnum (mynd 11). 


\section{Mynd 11. Hindranir í starfsumhverfi stjórnenda}

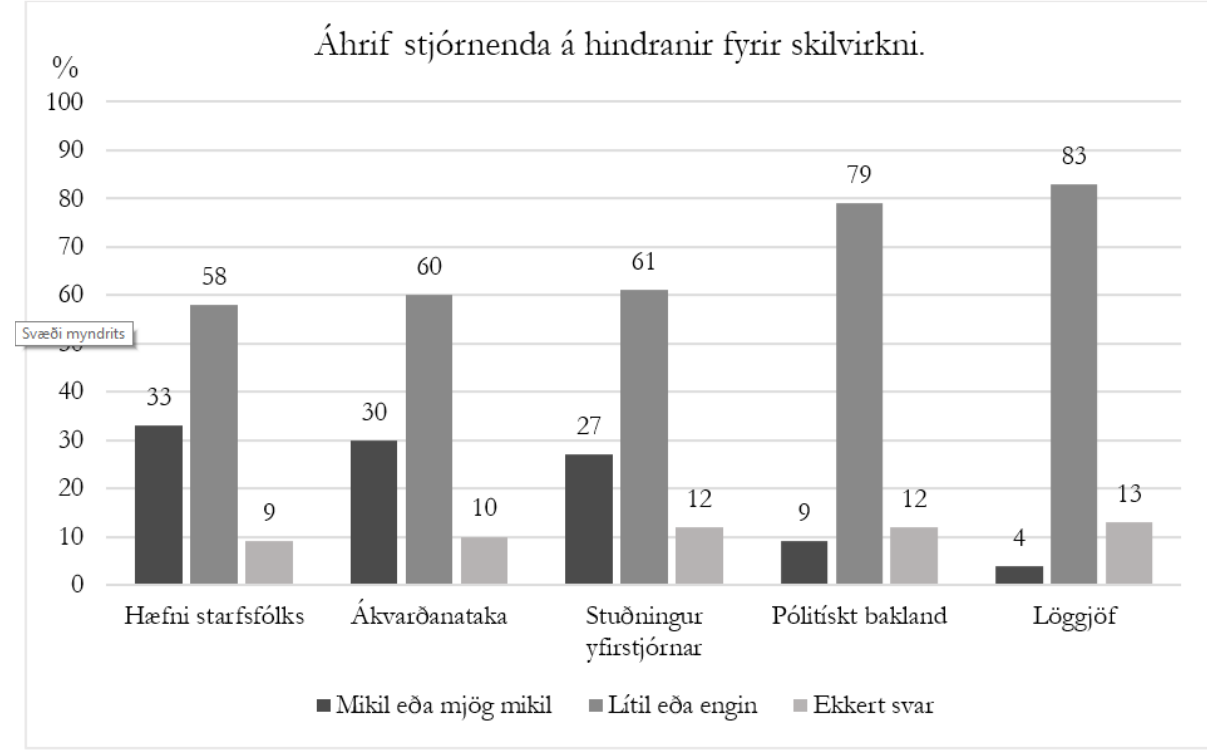

Helstu hindranir fyrir pví að auka árangur felast í að stjórnendur telja sig hafa lítil áhrif, sérstaklega á pólitískt bakland og löggjöf. Degar litið er til átta færnipátta opinberra stjórnenda (Dahl \& Søholm 2012) kemur í ljós að sérstaða opinberrar stjórnunar felist í að stjórnendur purfa að hafa pólitíska innsýn og ratvísi á opinberum vettvangi.

\section{Mynd 12. Helstu hindranir fyrir skilvirkni}

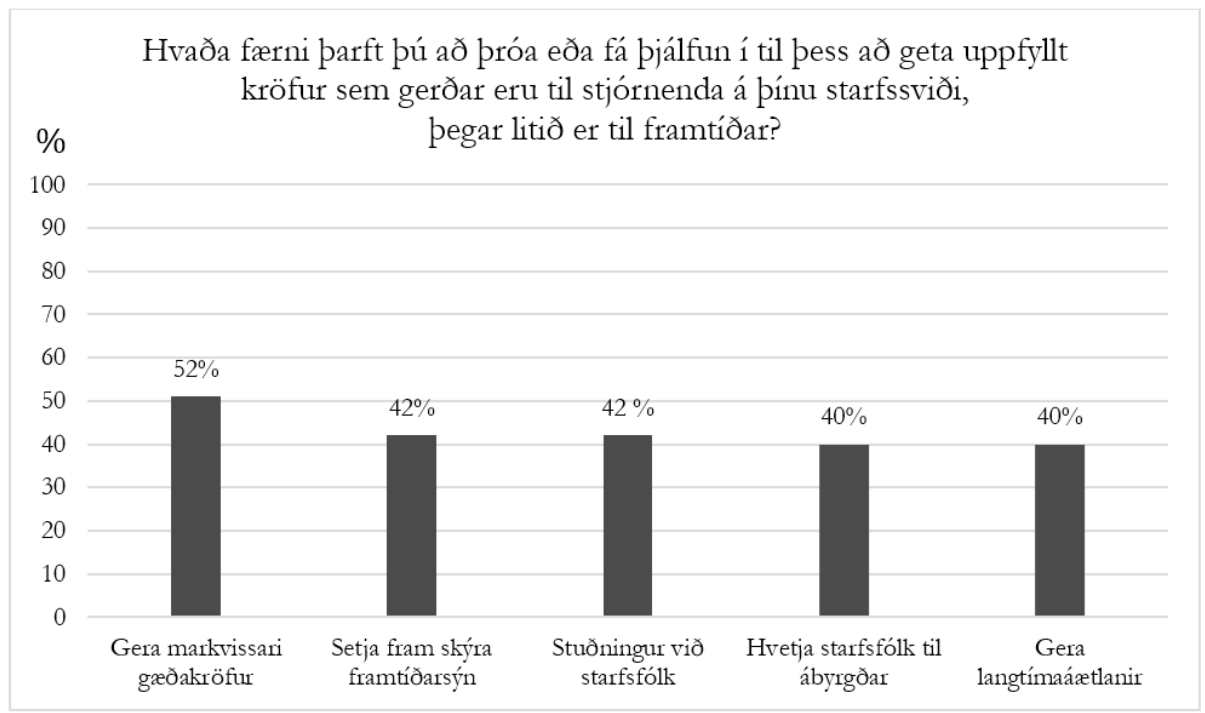


Degar litið er til áhrifa stjórnenda sem tóku afstöðu til spurningarinnar um hindranir fyrir skilvirkni og fylgni við bakgrunnsbreytur pá sagði um helmingur stjórnenda að skortur á stuðningi frá pólitísku baklandi væri hindrun fyrir skilvirkni í rekstri. Vera má að styrkur tengslanets og fyrri störf hafi áhrif á möguleika stjórnenda sem vilja beita sér á pólitíska sviðinu og má pví líta til pess hvort fylgni sé við aldur eða starfsreynslu. Fyrir tengsl milli tveggja flokkabreyta á raðkvarða má reikna fylgnistuðulinn $\gamma$ (Agresti \& Finlay 2008) og fyrir breytuna um áhrif á hindrun vegna skorts á pólitísku baklandi reynist fylgni við aldur og við starfsreynslu mælast lág og tölfræðilega ómarktæk (sjá mat á vikmörkum í töflu 8).

Tafla 8. Fylgni bakgrunnsbreyta við hindranir fyrir skilvirkni

\begin{tabular}{|c|c|c|c|c|c|c|c|c|c|}
\hline & \multicolumn{9}{|c|}{ Bakgrunnsbreytur } \\
\hline Mat á fylgnistuðli $\gamma$ og vikmörk & Reynsla & $95 \%$ örys & gisbil & Kyn & $95 \%$ öry & rgisbil & Aldur & $95 \%$ ör & rgisbil \\
\hline $\begin{array}{l}\text { pólitísku baklandi } \\
\text { Samanburður, áhrif á pekkingu og }\end{array}$ & 0,005 & $-0,122$ & 0,131 & 0,019 & $-0,159$ & 0,197 & $-0,087$ & $-0,223$ & 0,050 \\
\hline færni starfsfólks & 0,046 & $-0,071$ & 0,163 & 0,020 & $-0,148$ & 0,188 & $-0,089$ & $-0,220$ & 0,043 \\
\hline
\end{tabular}

Mynd 13. Dreifing svara eftir aldri, áhrif hindrunar um skort á stuđ̃ningi frá pólitísku baklandi fyrir skilvirkni

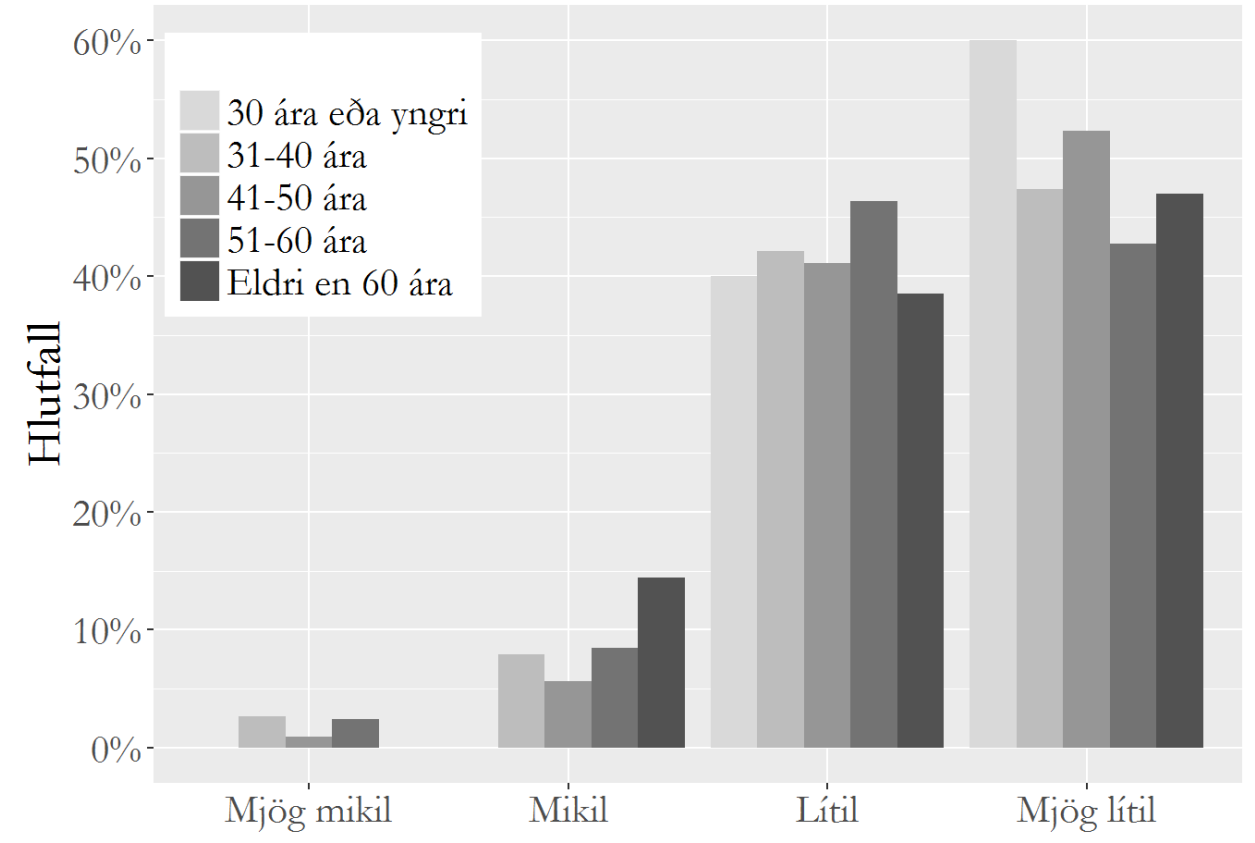

Fyrir spurningu um áhrif stjórnenda á hindrun vegna skorts á pekkingu og færni mælist fylgni við breytur einnig hverfandi og fyrir báðar pessar viðhorfsbreytur var einnig litið til pess hvort kyn stjórnenda hefði áhrif en svo reyndist ekki vera. 
Mynd 14. Dreifing svara eftir kyni, pegar spurt var um áhrif hindrunarinnar skort á stuđ̃ningi frá pólitísku baklandi fyrir skilvirkni

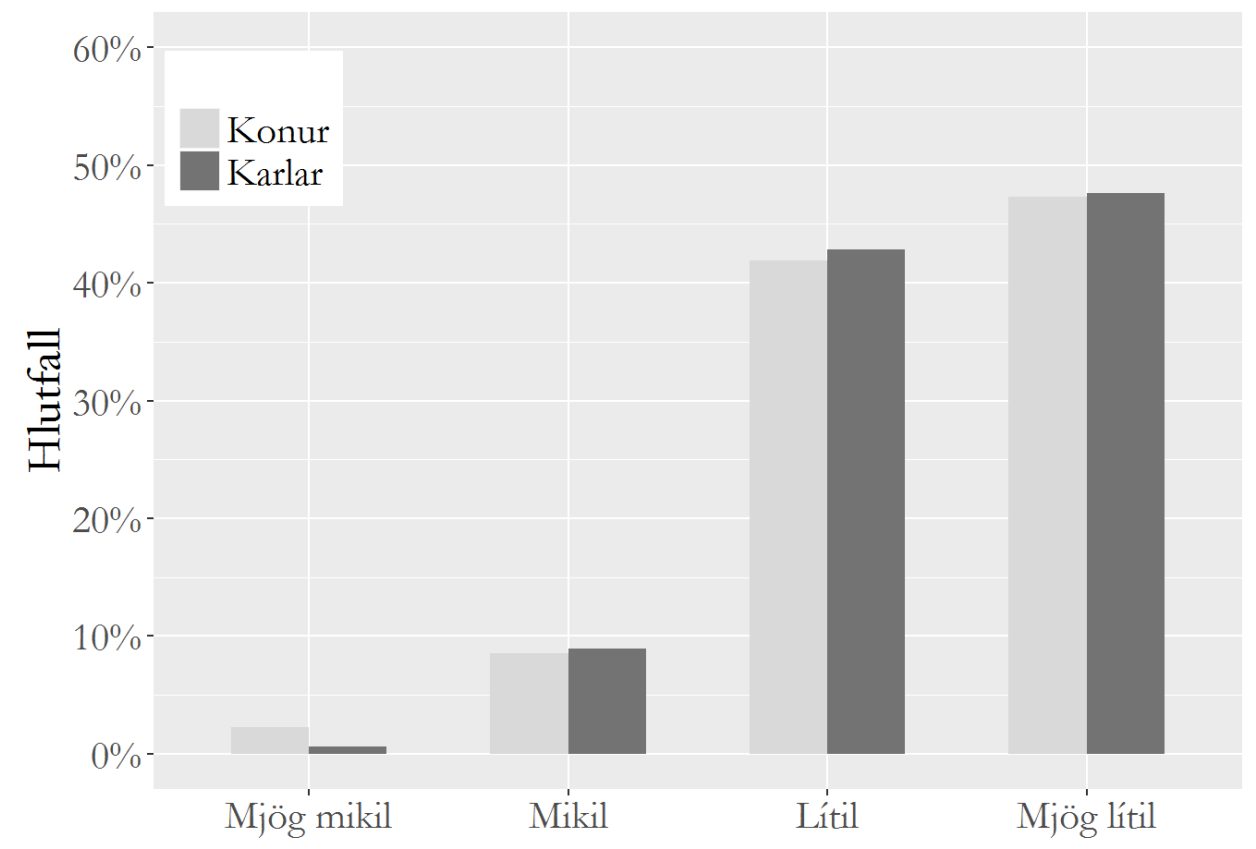

Af mynd 14 má til að mynda sjá að fyrir áhrif á hindrunina skort á stuðningi frá pólitísku baklandi er munurinn á dreifingu svara eftir kyni er afar lítill og viðhorfið ekki tölfræðilega marktækt háð kyni svarenda. 
Tafla 9. P-gildi fyrir kí-kvađrat tilgátupróf um tengsl milli viðhorfs- og bakgrunnsbreyta

\begin{tabular}{|c|c|c|c|c|c|c|c|c|c|}
\hline & Spurning & Menntun & & Reynsla & & Kyn & & Aldur & \\
\hline \multicolumn{10}{|c|}{ Fjárhagsleg rekstrarskilyrđi } \\
\hline \multirow[t]{5}{*}{ Mynd 3} & Breyta 1 & 0,45746 & - & 0,26836 & - & 0,02074 & * & 0,75984 & - \\
\hline & Breyta 2 & 0,14799 & - & 0,26836 & - & 0,24207 & - & 0,53937 & - \\
\hline & Breyta 3 & 0,69188 & - & 0,15631 & - & 0,24381 & - & 0,29882 & - \\
\hline & Breyta 4 & 0,06162 & - & 0,56913 & - & 0,54014 & - & 0,84969 & - \\
\hline & Breyta 5 & 0,18174 & - & 0,58759 & - & 0,1178 & - & 0,57122 & - \\
\hline \multicolumn{10}{|c|}{ Vinnuskipulag } \\
\hline \multirow[t]{4}{*}{ Mynd 4} & Breyta 1 & 0,42251 & - & 0,24848 & - & 0,02287 & * & 0,57017 & - \\
\hline & Breyta 2 & 0,00475 & $* *$ & 0,54872 & - & 0,06057 & - & 0,57248 & - \\
\hline & Breyta 3 & 0,01281 & $*$ & 0,09597 & - & 0,1155 & - & 0,61154 & - \\
\hline & Breyta 4 & 0,01676 & $*$ & 0,6626 & - & 0,16394 & - & 0,91758 & - \\
\hline \multicolumn{10}{|c|}{ Hindranir fyrir einföldun verkferla } \\
\hline \multirow[t]{5}{*}{ Mynd 5} & Breyta 1 & 0,27379 & - & 0,12328 & - & 0,25435 & - & 0,24013 & - \\
\hline & Breyta 2 & 0,46994 & - & 0,99483 & - & 0,3085 & - & 0,73606 & - \\
\hline & Breyta 3 & 0,49083 & - & 0,18933 & - & 0,93181 & - & 0,22586 & - \\
\hline & Breyta 4 & 0,25141 & - & 0,72089 & - & 0,76344 & - & 0,02612 & * \\
\hline & Breyta 5 & 0,88706 & - & 0,12507 & - & 0,67053 & - & 0,94499 & - \\
\hline \multicolumn{10}{|c|}{ Tengslanet } \\
\hline \multirow[t]{5}{*}{ Mynd 6} & Breyta 1 & 0,1552 & - & 0,6664 & - & 0,10959 & - & 0,41322 & - \\
\hline & Breyta 2 & 0,23176 & - & 0,26538 & - & 0,1087 & - & 0,03571 & * \\
\hline & Breyta 3 & 0,54313 & - & 0,13816 & - & 0,2667 & - & 0,47293 & - \\
\hline & Breyta 4 & 0,58078 & - & 0,07684 & - & 0,76309 & - & 0,35104 & - \\
\hline & Breyta 5 & 0,39326 & - & 0,04457 & * & 0,36902 & - & 0,80233 & - \\
\hline \multicolumn{10}{|c|}{ Kröfur um skjalfestar upplýsingar á vinnustað } \\
\hline \multirow[t]{6}{*}{ Mynd 7} & Breyta 1 & 0,18681 & - & 0,35558 & - & 0,08687 & - & 0,07472 & - \\
\hline & Breyta 2 & 0,7393 & - & 0,58562 & - & 0,45014 & - & 0,21019 & - \\
\hline & Breyta 3 & 0,11351 & - & 0,78915 & - & 0,64854 & - & 0,64886 & - \\
\hline & Breyta 4 & 0,69084 & - & 0,84214 & - & 0,65583 & - & 0,69289 & - \\
\hline & Breyta 5 & 0,78757 & - & 0,21315 & - & 0,4553 & - & 0,93695 & - \\
\hline & Breyta 6 & 0,5658 & - & 0,26204 & - & 0,81943 & - & 0,74818 & - \\
\hline \multicolumn{10}{|c|}{ Hindranir fyrir skilvirkni } \\
\hline \multirow[t]{5}{*}{ Mynd 8} & Breyta 1 & 0,78779 & - & 0,8124 & - & 0,6324 & - & 0,84352 & - \\
\hline & Breyta 2 & 0,71411 & - & 0,01105 & * & 0,98074 & - & 0,24218 & - \\
\hline & Breyta 3 & 0,47629 & - & 0,36896 & - & 0,45419 & - & 0,29495 & - \\
\hline & Breyta 4 & 0,94161 & - & 0,04414 & * & 0,70465 & - & 0,02284 & * \\
\hline & Breyta 5 & 0,99767 & - & 0,96562 & - & 0,41534 & - & 0,73599 & - \\
\hline
\end{tabular}

Núlltilgátan er sú að engin tölfræðilega marktæk tengsl séu milli viðhorfspáttar (röð) og bakgrunnsbreytu (dálkur) - ekki marktæk tengsl; * p-gildi $<0,1 ; * *$ p-gildi $<0,05$ 
Fyrir fullyrðingar pær sem lýst er í myndum 3 til 8 var reiknuð kí-kvaðrat prófstærð fyrir fylgni við fjórar bakgrunnsbreytur, menntun, reynslu, kyn og aldur. Рó svo að fyrir fáein tilvik hafi mælst merki um tölfræðilega marktæk tengsl, pá var p-gildi í flestum tilvikum hátt (sjá töflu 9) og gefur sú athugun ekki tilefni til að ætla að pessar bakgrunnsbreytur hafi markverð áhrif á upplifun stjórnendanna. Af peim fullyrðingum sem sýndu tengsl við bakgrunnsbreytur má nefna fullyrðingar um vinnuskipulag, en prjár peirra af fjórum sýna tölfræðilega marktæk tengsl við breytuna fyrir menntun. Fullyrðingarnar snúa að tækifærum til að hafa áhrif á eigið starf, tillit annarra stjórnenda og hvort nægur tími fáist til umhugsunar við ákvarðanatöku. Eftir pví sem menntun er meiri, peim mun meiri áhrif telja stjórnendur sig hafa og pví síður telja peir sig lenda í tímapröng pegar taka skal ákvarðanir. En að öðru leyti finnast ekki mjög afgerandi tengsl milli bakgrunnsbreytanna og peirra fullyrðinga sem svarendur lögðu mat á. Haft skal í huga að pegar p-gildi er reiknað fyrir mikinn fjölda prófstærða, líkt og gert er í töflu 9, pá er viðbúið að hendingar vegna sýni hluti peirra merki um tölfræðilega marktæk tengsl jafnvel pó engin slík séu til staðar.

Degar allar niðurstöður eru dregnar saman pá má sjá ákveðið mynstur. Helstu styrkleikar opinberrar stjórnunar á Íslandi felast í skýrum verkferlum, góðu skipulagi, stuttum boðleiðum og litlu skrifræði. Helstu veikleikarnir felast í litlum áhrifum á starfsfólk, aðra stjórnendur og lýðræðislega kjörna fulltrúa sem starfa í pólitísku baklandi og við löggjöf.

Viðhorf stjórnenda eru hér dregin saman í töflu 10 og nefnd drifkraftar og hindranir opinberra stjórnenda vegna pess hve mikil áhrif pau hafa á dagleg störf.

Tafla 10. Drifkraftar og hindranir í opinberri stjórnun á Íslandi

\begin{tabular}{l|l}
\hline Drifkraftar & Hindranir \\
\hline $\begin{array}{l}\text { Stjórnendur upplifa fjárhagslegt umhverfi í jafnvægi } \\
\text { par sem hæfilegar kröfur eru gerđar. }\end{array}$ & $\begin{array}{l}\text { Lítil áhrif á færni og pekkingu starfsfólks, stuðning } \\
\text { yfirstjórnar og stuðning við ákvarðanatöku. }\end{array}$ \\
\hline $\begin{array}{l}\text { Stjórnendur eru ánægđir með skipulagsleg skilyrđi í } \\
\text { vinnunni. }\end{array}$ & $\begin{array}{l}\text { Svigrúm til að færa fjármagn á milli ára pyrfti að vera } \\
\text { meira. }\end{array}$ \\
\hline $\begin{array}{l}\text { Lítið skrifræði gefur kost á einföldum verkferlum. } \\
\text { Traust ríkir í samskiptum á vinnustað og við } \\
\text { afhendingu gagna. }\end{array}$ & $\begin{array}{l}\text { Skjalfestar upplýsingar mætti nýta betur til úrbóta } \\
\text { og árangurs. }\end{array}$ \\
\hline $\begin{array}{l}\text { Sanngjarnar kröfur eru gerđar til skjalfestra } \\
\text { upplýsinga. }\end{array}$ & $\begin{array}{l}\text { Lítil áhrif á pólitískt bakland og löggjöf hindrar } \\
\text { árangur. }\end{array}$ \\
\hline
\end{tabular}

\subsection{Samanburđur á íslenskum og dönskum stjórnendum}

Pegar borin eru saman verkefni og viðhorf danskra og íslenskra stjórnenda pá koma fram mörg sameiginleg einkenni. Stjórnendur í báðum löndum eru að mestu leyti ánægðir með skipulagsleg og fjárhagsleg skilyrði par sem peir telja hæfilega miklar kröfur gerðar til peirra, samskipti eru góð og tengslanetið á vinnustaðnum mikilvægt. Í töflu 11 eru helstu drifkraftar og hindranir danskra stjórnenda. 


\section{Tafla 11. Drifkraftar og hindranir í opinberri stjórnun í Danmörku}

\begin{tabular}{l|l}
\hline Drifkraftar & Hindranir \\
$\begin{array}{l}\text { Stjórnendur upplifa fjárhagslegt umhverfi í jafnvægi par } \\
\text { sem hæfilegar kröfur eru gerđar. }\end{array}$ & $\begin{array}{l}\text { Svigrúm til að færa fjármagn á milli ára mætti } \\
\text { vera meira. }\end{array}$ \\
$\begin{array}{l}\text { Gott aðgengi er að næsta yfirmanni til að ræđa vandamál. } \\
\text { Vilji er til að hafa meiri áhrif í } \\
\text { ákvarđanatökuferlum. }\end{array}$ \\
$\begin{array}{l}\text { Stjórnendur upplifa öryggi við afhendingu gagna vegna } \\
\text { vinnu sinnar. }\end{array}$ & Ósk um færri kröfur um skjalfestar upplýsingar. \\
$\begin{array}{l}\text { Góð tengsl eru á vinnustađnum, opin samskipti og traust } \\
\text { ríkir. }\end{array}$ & $\begin{array}{l}\text { Lítil áhrif á pólitískt bakland og löggjöf hindrar } \\
\text { árangur. }\end{array}$ \\
$\begin{array}{l}\text { Upplifun af pví ađ geta haft áhrif á skilvirkara vinnulag, } \\
\text { varđandi skort á pekkingu, færni og ákvarđanatökuferla. }\end{array}$ & $\begin{array}{l}\text { Löggjöf hindrar einföldun verkferla og er sú } \\
\text { hindrun sem stjórnendur hafa minnst áhrif á. }\end{array}$ \\
\hline
\end{tabular}

Hindranir stjórnenda eru keimlíkar par sem stjórnendur í báðum löndum telja miklar hindranir vera gagnvart löggjöf og pólitísku baklandi.

\section{Mynd 15. Samanburđur, áhrif á stuđning frá pólitísku baklandi}

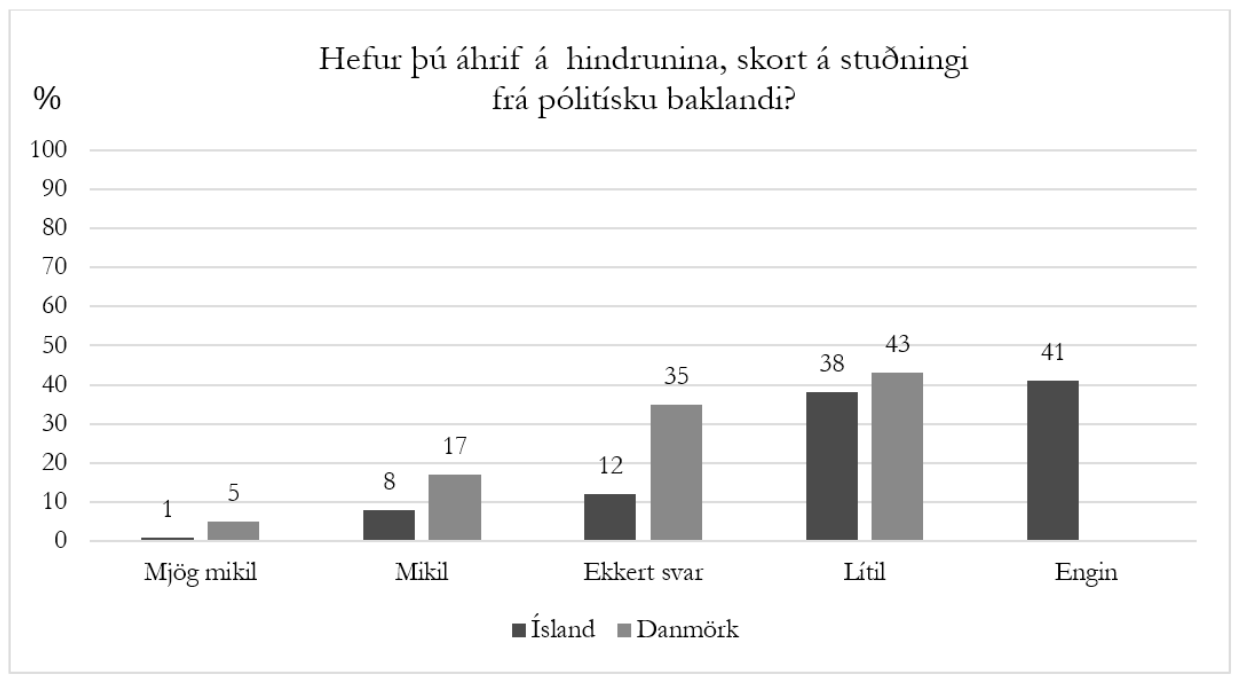

Mynd 15 sýnir mun íslenskra og danskra stjórnenda í svörum á fullyrðingum um hvort peir telji sig hafa áhrif á hindranir sem varða stuðning frá pólitísku baklandi en íslenskir stjórnendur eru meira afgerandi í svörum sínum.

Opinberir stjórnendur beggja landa upplifa fleiri hindranir með svipuðum hætti. Til dæmis að lítið svigrúm sé til að færa fjármagn á milli ára og einnig að betur mætti nýta skjalfestar upplýsingar og tímaskortur í ákvarðanatökuferlum. 
pegar skoðað er hvað er ólíkt á milli landanna voru tvö atriði sem skáru sig úr. Annars vegar að íslenskir stjórnendur eru sáttari en danskir stjórnendur við kröfur um skjalfestar upplýsingar, par sem vísbendingar eru um að opinbera stjórnkerfið á Íslandi sé ekki bundið í eins fastar skorður skrifræðis og danska stjórnkerfið. Pannig telja einungis 40\% íslenskra stjórnenda vera ónauðsynlegt skrifræði á vinnustaðnum á meðan 63\% danskra stjórnenda telur svo vera, mynd 16.

\section{Mynd 16. Samanburđur, skrifræđi á vinnustað}

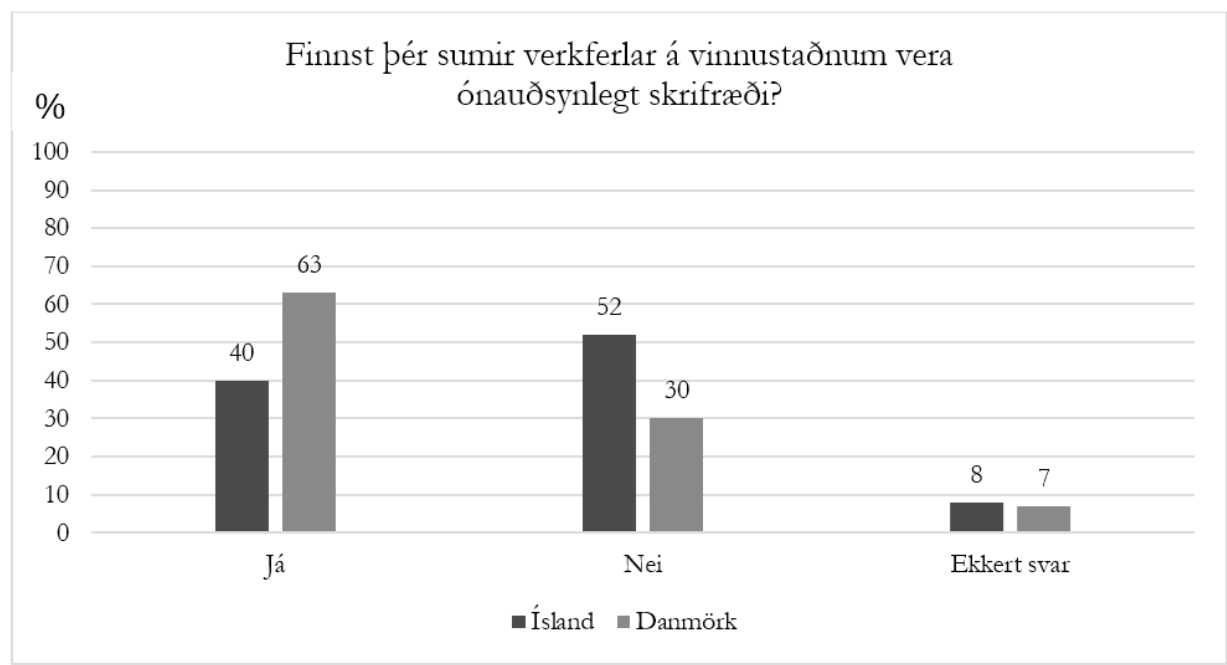

Hins vegar kemur fram að danskir stjórnendur telja sig hafa meiri áhrif á innra umhverfi en íslenskir stjórnendur. Mikill meirihluti danskra stjórnenda (77\%) telur sig geta aukið skilvirkni á vinnustaðnum með pví að hafa áhrif á hindranir sem tengjast pekkingu og færni starfsmanna. Íslenskir stjórnendur telja sig hafa mun minni áhrif á pekkingu og færni starfsmanna, einungis 33\% stjórnenda telur sig geta haft áhrif á pessa hindrun. 


\section{Mynd 17. Samanburður, áhrif á pekkingu og færni starfsfólks}

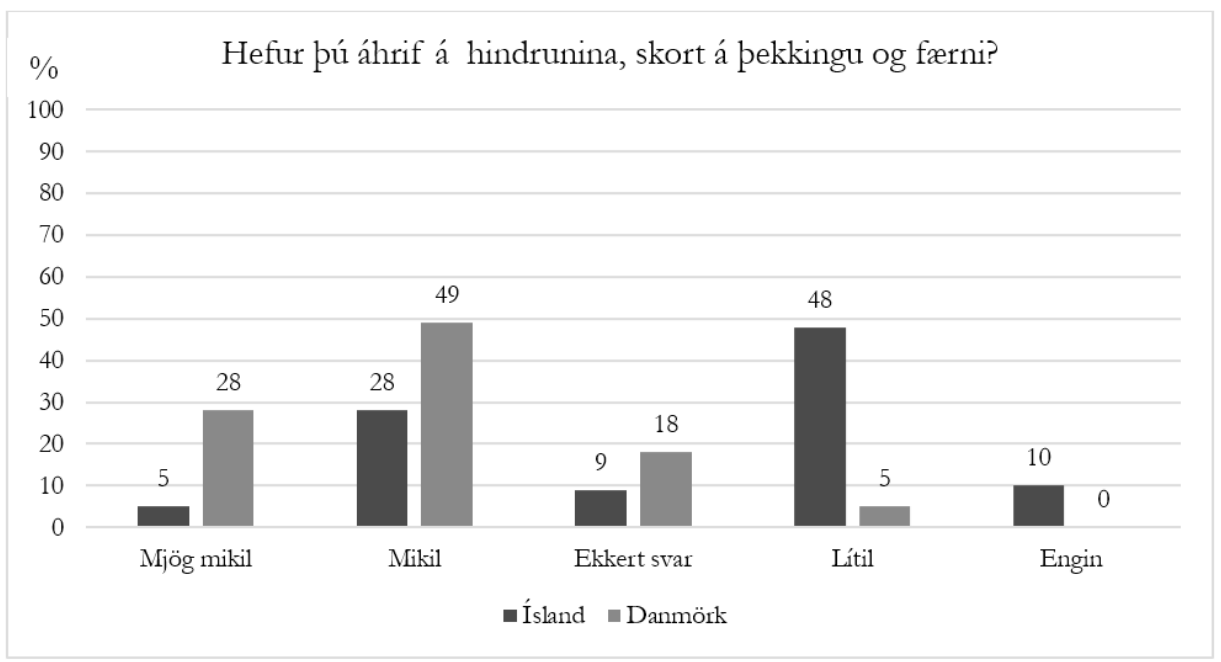

Skoða má pessa pætti í tengslum við mikilvægar forystuaðgerðir sem fela meðal annars í sér að hafa áhrif, skapa skilning og samhengi (Yukl, 2006).

\section{Umræður}

Niðurstöðurnar í íslensku rannsókninni gefa nokkuð skýrar vísbendingar sem geta stutt umbætur í starfsumhverfi opinberra stjórnenda á Íslandi. Fram kemur að stjórnendur eru almennt ánægðir með starfsumhverfið en meirihluti peirra telur mögulegt að auka árangur en eiga erfitt með að átta sig á hvaða hlutverki peir gegna pegar kemur að pví að takast á við hindranir. Dahl og Søholm (2012) benda á að hlutverk stjórnenda purfa að vera skýr og í úttekt Ríkisendurskoðunar um áherslur í árangursstjórnun í ríkisrekstri er bent á að betur mætti gera til að samræma verklag og heildarnálgun (Ríkisendurskoðun 2003). Ýmis tækifæri eru til að skapa nýjar lausnir og auka svigrúm í opinberri stjórnun með pví að hrinda hindrunum úr vegi, leggja áherslu á færni starfsfólks og miðla upplýsingum með markvissum hætti. Sørensen (2015) bendir á að kröfur eru um að bæta opinbera pjónustu en á sama tíma parf að nýta auðlindir á hagstæðan hátt og vera skapandi í lausnum. Í grein um íslenska vinnustaðamenningu kemur fram að íslenskar skipulagsheildir hafa skýra sýn og markmið en mikilvægt er að skilgreina ferla og samstarfsfleti betur á milli starfseininga og vísbendingar eru um að sameiginleg gildi skorti og lítill vilji sé til breytinga (Gylfi Dalmann Aðalsteinsson o.fl. 2010). Petta samræmist niðurstöðu rannsóknarinnar um hindranir fyrir árangri par sem einnig koma fram vísbendingar um að stjórnendur purfi betur skilgreinda samstarfsfleti og ef til vill meiri vilja til breytinga.

Dahl og Søholm (2012) hafa bent á mikilvægi pess að stjórnendur kunni leikreglurnar á pólitískum vettvangi og vinni með almenningi ekki síður en með starfsfólki. Skýra parf frá árangri, miðla upplýsingum til peirra sem valdið hafa og hafa áhrif á ákvarðanatöku. 


\section{STJÓRNMÁL \& \\ STJÓRNSÝSLA}

Út frá niðurstöðum um helstu hindranir má álykta að leggja purfi áherslu á árangursrík samskipti við lýðræðislega kjörna fulltrúa á hinum pólitíska vettvangi. Degar skoðuð eru lykilatriði í stjórnun eins og peim er lýst hjá Sørensen (2015) kemur fram að verkefni stjórnandans er að móta sameiginlega sýn, samhæfa aðgerðir og skapa skuldbindingu. Gera má ráð fyrir að áfram verði mikil pörf fyrir að starfa náið með lýðræðislega kjörnum fulltrúum og öðrum hagsmunaaðilum til að auka árangur í opinberum rekstri sem fellur að pví sem fram kemur hjá Gunnari Helga Kristinsyni (2007) um að stofnanir beri ábyrgð á að sinna pörfum íbúa í flóknu og óvissu umhverfi og purfi stjórnendur að vera meðvitaðir um pólitíska forystu.

Íslenskir stjórnendur telja hæfilegar kröfur gerðar til peirra en á sama tíma telja peir að betur mætti nýta upplýsingar til að auka árangur. Einnig kemur fram að íslenskir stjórnendur telja mikilvægt að hafa skjalfestar upplýsingar, prátt fyrir að peir noti pær ekki nema stöku sinnum til að bæta árangur í starfsemi eigin stofnunar. Eitt einkenni norrænnar stjórnunar er langir vinnuferlar par sem margir koma að ákvarðanatöku (Larsen \& Neergaard 2007) sem stundum leiðir af sér að ákvarðanir eru teknar seint eða að enginn tekur ákvörðun. Mögulegt er að vinna að markvissari gæðastjórnun með pví að taka ákvarðanir um hvaða gögn er mikilvægt að vinna með áfram, hvernig unnið er með gögn innan stofnana og hvernig upplýsingum er miðlað. Bent hefur verið á að opinber stjórnun einkennist af flóknu samspili par sem taka parf tillit til margra ólíkra sjónarmiða, skráning gagna og verkferlar purfa að vera skýrir (Solsø \& Thorup 2015). Auk pess parf að hafa í huga að löggjöf hefur mikil áhrif og takmarkar ákvörðunarvald opinberra stjórnenda (Ingi Rúnar Eðvarðsson \& Ása Líney Sigurðardóttir 2010). Athygli vekur að ekki virðist vera um mun á niðurstöðum að ræða hjá íslensku stjórnendunum varðandi bakgrunnsbreytur og gæti pað gefið tilefni til frekari rannsókna með fleiri rannsóknaraðferðum.

Stjórnunarstíll á Norðurlöndum einkennist af sameiginlegum ferlum par sem starfsmenn eru virkir pátttakendur og hann er mótaður af gildum eins og jafnræði, samvinnu og sveigjanleika (Larsen \& Neergaard 2007). Starfsumhverfi íslenskra og danskra stjórnenda og verkefni peirra falla vel að pessum gildum prátt fyrir að nokkur munur sé á niðurstöðum rannsóknanna. Mikilvægt er að hafa í huga að prátt fyrir að Norðurlöndin hafi sameiginleg gildi pá hefur hvert land hefur sín sérkenni. Fjölbreytileikinn í norrænni stjórnun skapar árangursríkar, stefnumarkandi lausnir og starfsánægju segja Larsen o.fl. (2015) og benda á að traust myndast í starfsmannahópi pegar samstarf er gott. Í rannsókn Lindell og Arvonen (1994) um norræna stjórnun í samanburði við önnur Evrópulönd kemur meðal annars fram að sérstaða Norðurlanda felst í góðu skipulagi, opnum samskiptum og dreifðri ábyrgð. Tvö fyrstnefndu atriðin falla vel að niðurstöðu íslensku rannsóknarinnar en sterkar vísbendingar koma fram um að betur mætti gera í að dreifa ábyrgð og hafa áhrif. Einnig benda Lindell og Arvonen (1994) á að pað sem aðskilur norræna stjórnendur frá öðrum Evrópulöndum er mikil áhersla á skipulag og reglu, að deila ábyrgð og hafa gott samband við starfsfólk. Рað rímar einnig vel við pað sem Ásta Dís Óladóttir og Ragnheiður Jóhannesdóttir (2008) benda á sem einkenni íslenskra stjórnenda, sem eru meðal annars einstaklingshyggja, opin samskipti, sveigjan- 
leiki og frumkvöðlahneigð en áherslur danskra stjórnenda er á dreifða ábyrgð, óformleg samskipti, virðingu, hvatningu og faglega færni. Dað má álykta út frá pessu að í niðurstöðum rannsóknanna komi sérkenni landanna í ljós í verkefnum og viðhorfum par sem styrkleikar íslenskra stjórnenda koma fram í einföldum og skýrum verkferlum á meðan styrkleikar danskra stjórnenda felast í að hafa áhrif á starfsfólkið. Spurning er hvort einhverjar hindranir geti legið í samskiptum við verkalýðsfélög eða stífa túlkun kjarasamninga hér á landi sem skýri upplifun íslenskra stjórnenda um minni áhrif á starfsfólk. Gæti petta gefið tilefni til frekari rannsókna um mun á milli landanna.

Áherslur í framtíðarsýn um norræna forystu benda til pess að áhrif frá pólitísku baklandi muni spila stærra hlutverk í opinberri stjórnun par sem krafa er frá almenningi um að lýðræðislega kjörnir fulltrúar taki samfélagslega ábyrgð og leysi brýn málefni hratt ásamt kröfu um sýnileika og gegnsæi í ákvarðanatökum (Dølvik o.fl. 2014; Vækstuhus for ledelse 2014). Berlega kemur í ljós í niðurstöðum beggja rannsóknanna að mikill meirihluti stjórnenda telur sig hafa lítil eða mjög lítil áhrif á pólitískt bakland og löggjöf. Athyglisvert væri að gera frekari rannsóknir á opinberri stjórnsýslu á Íslandi í pólitísku samhengi og skoða leiðir sem hvetja til samstarfs á milli lýðræðislega kjörinna fulltrúa og stjórnenda.

Bæði danskir og íslenskir stjórnendur telja að í framtíðinni verði gerðar meiri kröfur til gæða og að peir purfi að efla færni sína í markvissara gæðastarfi. Innleiðing og framkvæmd gæðastefnu gæti verið verðugt viðfangsefni til að vinna meira með í stofnunum eða í frekari rannsóknum. Fjölmargar vísbendingar er að finna í niðurstöðum pessarar rannsóknar sem benda til pess að með markvissari gæðastjórnun væri hægt að bæta árangur út frá stjórnunarstíl norrænnar forystu. Pessir pættir falla vel að niðurstöðum rannsóknar um pekkingarstjórnun og pekkingarmiðlun, par sem kröfur eru gerðar um vel upplýsta starfsmenn sem geta veitt sérfræðipjónustu á viðkomandi starfssviði (Hildur Ösp Gylfadóttir \& Ingi Rúnar Eðvarðsson 2012).

एað er von höfunda að pessi rannsókn geti varpað gagnlegu ljósi á starfsumhverfi opinberra stjórnenda á Íslandi.

\section{Heimildir}

Agresti, A. og Finlay, B. (2008). Statistical Methods for the Social Sciences. (4. útg.). USA: Pearson. Andersen N.Å. og Pors J.G. (2014). Velfardsledelse. Denmark: Hans Reitzels Forlag.

Armstrong, M. (2014). Handbook of Human Resource Management Practice (13. útg.). UK: Kogan Page.

Árelía Guðmundsdóttir og Jón Guðjónsson (2013). Skapandi sveigjanleiki. Í Ingjaldur Hannibalsson (ritstj.), Djóđarspegilinn XIV. Félagsvísindastofnun Háskóla Íslands. Sótt 15. júlí 2015 frá http:// skemman.is/stream/get/1946/16764/38997/1/AreliaJon_VID.pdf.

Ásta Dís Óladóttir og Ragnheiður Jóhannesdóttir (2008). Íslenskir stjórnendur í norrænum samanburði. Bifröst Journal of Social Science, 2, 47-67. Sótt 28. apríl 2015 frá http://bjss.bifrost.is/index.php/bjss/ article/viewFile/23/42.

Bennis, W og Nanus, B. (1985). Leaders: The Strategies for Taking Charge. New York: Harper. Row.

Bentzen, T.Ø. (2015). De offentlige ledere og Tillidsaftalen-barrierer og drivkræfter. Í T.J. Rasmussen (ritstj.), Offentlig ledelse, 1. Sótt 14. október 2015 frá Offentlig ledelse: http://offentligledelse.dk/wpcontent/uploads/Tillidsunders $\% \mathrm{C} 3 \%$ B8gelse-final.pdf

Burnes, B. (2014). Managing Change. Harlow: Pearson. 


\section{STJÓRNMÁL $\&$ \\ STJÓRNSÝSLA}

Correia M. og van Dierendonck K. (2010). „The knowledge worker, servant leadership and the search for meaning in knowledge-driven organizations", On the Horizon 18 (3), 230.

Dahl, K. og Søholm, M. T. (2012). Leadership Pipeline i den offentlige sektor (2. útg.). Dansk Psykologisk Forlag A/S.

Dølvik, J. E., Fløtten, T., Hippe, J. M. og Jordfald, B. (2014). Den nordiske modellen mot 2030. Et nytt kapittel. Fafo. Sótt 28. september 2015 frá http://www.fafo.no/index.php/en/publications/fafo-reports/ item/den-nordiske-modellen-mot-2030-et-nytt-kapittel.

Ejersbo, N. og Greve, C. (2014). Sådan har lederrollen udviklet sig over 30 år. (Væksthus for ledelse) Sótt frá Lederweb: http://www.lederweb.dk/dig-selv/lederrollen/artikel/113555/dit-lederskab-erpavirket-af-udviklingen-i-ledelsestankningen-i-moderniseringen-af-den-offentlige-sektor.

Eriksen T.T., Kruse M. og Larsen G. (2006). The Scandinavian Way. Sótt frá Copenhagen Institute for Future Studies-Instituttet for fremtidsforskning: http:/ /www.cifs.dk/scripts/artikel.asp?id=1481\&lng=2.

Fiedler, F. (1967). A Theory of Leadership Effectiveness. New York: Mc Graw-Hill.

Fjármálaráðuneytið. (2011). Staða árangursstjórnunar í opinberum rekstri. Sótt 9. mars 2017 frá https:// www.fjarmalaraduneyti.is/media/arangursstjornun/Stada_arangursstjornunar_i_opinberum_ rekstri_08_2011.pdf.

Gunnar Helgi Kristinsson (2007). „Lýðræðisleg ábyrgð og rekstrarform stjórnsýslu“, Stjórnmál og stjórnsýsla 2 (3), 224-234. Sótt 25. september 2015 frá Stjórnmál og stjórnsýsla: http://skemman.is/ stream/get/1946/8955/23846/1/b.2007.3.2.2.pdf.

Gylfi Dalmann Aðalsteinsson, Svala Guðmundsdóttir og Pórhallur Örn Guðlaugsson (2011). „Íslensk pjóðmenning í ljósi menningarvídda Hofstede“, Stjórnmál og stjórnsýsla 7 (2), 353-368. Sótt 9. mars frá Stjórnmál og stjórnsýsla: http://skemman.is/stream/get/1946/9132/24030/1/a.2010.6.2.5.pdf.

Gylfi Dalmann Aðalsteinsson, Dórhallur Örn Guðlaugsson og Ester Rós Gústavsdóttir (2010). „Íslensk vinnustaðamenning: Skýr og markviss stefna en skortur á samhæfingu og sampættingu“, Stjórnmál og stjórnsýsla 6 (2), 229-251.

Harpa Björg Guðfinnsdóttir og Inga Jóna Jónsdóttir (2005). „Starfshæfnílitlum og meðalstórum fyrirtækjum“, Djódarspegill. Sótt 7. október 2015 frá http://skemman.is/stream/get/1946/13628/32598/1/ Grein_\%C3\%9Ej\%C3\%B3\%C3\%B0arspegill_2005_\%C3\%9Er\%C3\%B3un_stj\%C3\%B3rnendah\%C3\%A6fni_\%C3\%AD_SME.pdf

Haukur Ingi Jónasson og Helgi Pór Ingason (2011). Leiðtogafarni. Sjálfskilningur, proski og próun. Reykjavík: JPV útgáfa.

Hildur Ösp Gylfadóttir og Ingi Rúnar Eðvarðsson (2012). „Dekkingarmiðlun í stjórnsýslu sveitarfélaga“, Stjórnmál og stjórnsýsla, 2 (8), 343-366. Sótt 25. september 2015 frá http://skemman.is/stream/get/ 1946/14848/34881/1/a.2012.8.2.8.pdf.

House, R.J., Hanges, P.J., Javidan, M., Dorfman, P.W. og Gupta, V. (2004). Culture, Leadership, and Organization: The GLOBE Study of 82 Societies. Thousand Oaks, USA: Sage Publications.

Ingi Rúnar Eðvarðsson og Ása Líney Sigurðardóttir (2010). „Ákvarðanataka skipulagsheilda“, Stjórnmál og stjórnsýsla, 6 (2), 253-275. Sótt frá http://skemman.is/stream/get/1946/9133/24032/1/ a.2010.6.2.6.pdf

Ingi Rúnar Eðvarðsson og Guðmundur Kristján Óskarsson (2009). „Íslenskir stjórnendur: Einkenni, stjórnunaraðferðir og árangur", Bifröst Journal of Social Science 1, 45-65. Sótt frá http://skemman.is/ stream/get/1946/10895/26908/1/Ingi_Runar_Edvardsson_2.pdf.

Klausen, K.K. (2001). Skulle det vare noget sarligt. Organisation og ledelse $i$ det offentlige. Kaupmannahöfn: Börsen Forlag.

Kotter, J.P. (2012). Leading Change. Boston, Massachusetts, USA: Harvard Business Review Press.

Lægaard, J. (2014). Det strategiske lederskab. Danmörk: Hans Reitzels Forlag.

Larsen, H.H. og Neergaard, U.B. (ritsti.). (2007). Nordisk Lys. Et forprojekt om nordisk ledelse og ledelse i Norden. De nordiske kommunale arbejdsgiverorganisationer. Sótt 20. apríl 2015 frá http://www. kl.dk/ImageVaultFiles/id_34173/cf_202/Nordisk_Lys_-_dansk_pixibog.PDF. 
Larsen, P., Vestergaard, B. og Guarini, M. (2015). New Nordic Leadership-fair ledelse og strategi. Sótt frá New Nordic Leadership institute: http://www.nnli.org/uploads/2/9/4/1/29412281/new_nordic_ leadership.pdf.

Lindell, M. og Arvonen, J. (1994). The Nordic management style in a European context, 286. Stokkhólmur: Meddelanden från Svenska Handelshögskolan.

Lund, H.R. og Reich, K. (2013). Work-life balance 2.0. Kaupmannahöfn: Gyldendal.

Mandag Morgen. (2005). Norden som global vinderregion. På sporet af den nordiske konkurrencemodel. Húsið Mandag Morgen í samvinnu við Norrænu ráðherranefndina.

Mintzberg, H. (2011). Managing. Great Britain: Pearson Education Limited.

Northouse, P.G. (2016). Leadership and Practice. (7.útg.). USA: Sage Publications, Inc.

Ómar H. Kristmundsson (ritstj.) (1999). Starfsumbverfi ríkisstarfsmanna við aldahvörf. Fjármálaráðuneytið.

Poulsen, K.M. (2010). Mentorguiden-om mentorskab og en-til-en relationer. Hørsholm, Danmörk: KMP Forlag.

Poulsen, P.T. (1987). Den samstemte virksombed. Kaupmannahöfn, Danmörk: Schultz Forlag.

Renison, B.W. (2000). Offentlig ledelse? - en fortalling om fortallingen om New Public Management og et alternativt studie på vej. Kaupmannahöfn, Danmörk: Copenahgen Business School. Sótt 6. október 2015 frá http://openarchive.cbs.dk/handle/10398/6407.

Ríkisendurskoðun (2003). Nádist árangur? Úttekt á árangursstjórnun i ríkisrekestri. Sótt 9. mars 2017 frá http://rikisendurskodun.is/wp-content/uploads/2016/01/nadist_arangur.pdf.

Social- og indenrigsministeriet (2013). Principper for samarbejde mellem parter på det offentlige arbejdsmarked om modernisering. Sótt 9. júlí 2015 frá oim.dk: http://oim.dk/media/502155/Principper\%20for\%20 samarbejde $\% 20$ mellem $\% 20$ parter $\% 20$ på\%20det $\% 20$ offentlige $\% 20$ arbejdsmarked $\% 20$ om $\% 20$ moderniserin1.pdf.

Solsø, K. og Thorup, P. (2015). Ledelse i kompleksitetet. Viborg, Danmörk: Dansk Psykologisk Forlag A/S. Svendsen, G.T. (2015). ,'Tillid sparer penge“, Offentlig ledelse 1, 4-5. Sótt frá http://offentligledelse.dk/ wp-content/uploads/Offentlig-ledelse-01-15_web.pdf.

Sørensen, H. D. (2015). Ny velfard - nyt lederskab. Danmörk: Dansk Psykologisk Forlag A/S.

van Hauen, F., Kastberg, B. og Soden, A. (2008). Tor du kysse froen. Kaupmannahöfn, Danmörk: Peter Asschenfeldts nye Forlag.

van Wright, G. H. (2003). Framfaragoðsögnin. Reykjavík: Hið íslenska bókmenntafélag.

Velstandsgruppen og Mandag Morgen (2015). Supermodel Danmark. Sótt 7. júlí 2015 frá mm.dk: https:// www.mm.dk/supermodel-danmark.

Væksthus for ledelse (2008). Ledere der lykkes. Sótt 31. maí 2015 frá Lederweb.dk: http://www.lederweb. $\mathrm{dk} /$ ImageVault/Images/id_41623/scope_0/ImageVaultHandler.aspx.

Væksthus for ledelse (2014). Sådan har lederrollen udviklet sig over 30 år. Sótt 26. september 2015 frá Lederweb: http://www.lederweb.dk/dig-selv/lederrollen/artikel/113555/dit-lederskab-er-pavirketaf-udviklingen-i-ledelsestankningen-i-moderniseringen-af-den-offentlige-sektor.

Yukl, G. (2006). Leadership in organizations. USA: Pearson.

Pórunn Kristín Sigurðardóttir (2013). Maður er alltaf að leita lausna. Óbirt lokaverkefni til MS-prófs 1̂ stjórnun heilbrigðispjónustu, viðskiptafræðideild Háskólans á Bifröst. Sótt 31. maí 2015 frá http:/ / skemman.is/stream/get/1946/16893/39146/1/Lokaritger\%C3\%B0_2013_\$0028pdf\$0029.pdf. 